\title{
Can Conservation Tillage and Residue Management Effects on Sensitivity of Labile Soil Organic Carbon Fractions and Soil Organic Carbon Stocks in Sub-Tropical Ecosystems: A Review
}

\author{
Rajendra Kumar ${ }^{1 *}$, R.K. Naresh ${ }^{1}$, Mohan Lal ${ }^{1}$, D.K. Sachan ${ }^{2}$, N.C. Mahajan ${ }^{3}$, \\ Sanjeev Singh ${ }^{1}$, Omkar Singh ${ }^{4}$, Rahul Kumar ${ }^{1}$ and Vishal Chaudhary ${ }^{1}$
}

\author{
${ }^{1}$ Department of Agronomy, ${ }^{4}$ Department of Soil Science, Sardar Vallabhbhai Patel University \\ of Agriculture \& Technology, Meerut-250110, U.P., India \\ ${ }^{2}$ K.V.K. Ghaziabad, India \\ ${ }^{3}$ Institute of Agricultural Science, Department of Agronomy, Banaras Hindu University, \\ Varanasi, U. P., India \\ *Corresponding author
}

\section{Keywords \\ Labile SOM dynamics, Conservation tillage, Macro-aggregates, Micro- aggregates, Fractionation, Particulate organic carbon, Soil Organic Carbon}

\section{Article Info}

Accepted:

15 October 2018 Available Online:

10 November 2018

\section{A B S T R A C T}

The effects of tillage and residue management on labile soil organic carbon fractions and soil organic carbon stocks can vary spatially and temporally, and for different soil types and cropping systems. Surface soil $(0-15 \mathrm{~cm})$ was fractionated into aggregate sizes $(>4.76 \mathrm{~mm}$, 4.76-2.00 mm, 2.00-1.00 mm, $1.00-0.25 \mathrm{~mm}, 0.25-0.053 \mathrm{~mm},<0.053 \mathrm{~mm}$ ) under different tillage regimes. Tillage significantly reduced the proportion of macro-aggregate fractions $(>2.00 \mathrm{~mm})$ and thus aggregate stability was reduced by $35 \%$ compared with (ridge with no tillage) RNT, indicating that tillage practices led to soil structural change for this subtropical soil. The highest SOC was in the $1.00-0.25 \mathrm{~mm}$ fraction $\left(35.7\right.$ and $30.4 \mathrm{mgkg}^{-1}$ for RNT and $\mathrm{CT}$, respectively), while the lowest SOC was in micro-aggregate $(<0.025 \mathrm{~mm})$ and silt + clay $(<0.053 \mathrm{~mm}$ ) fractions (19.5 and $15.7 \mathrm{mg} / \mathrm{kg}$ for RNT and CT, respectively). Labile C fractions: particulate organic $\mathrm{C}$ (POC), microbial biomass $\mathrm{C}$ (MBC) and dissolved organic $\mathrm{C}$ (DOC) were all significantly higher in NT and ST than in CT in the upper $15 \mathrm{~cm}$. The portion of 0.25- $2 \mathrm{~mm}$ aggregates, mean weight diameter (MWD) and geometric mean diameter (GMD) of aggregates from ST and NT treatments were larger than from CT at both 0-15- and 15-30-cm soil depths. Positive significant correlations were observed between SOC, labile organic $\mathrm{C}$ fractions, MWD, GMD, and macro-aggregate $(0.25-2 \mathrm{~mm}) \mathrm{C}$ within the upper 15 $\mathrm{cm}$. Tillage did not influence the patterns in SOC across aggregates but did change the aggregate-size distribution, indicating that tillage affected soil fertility primarily by changing soil structure. The average concentration of particulate organic carbon (POC), dissolved organic carbon (DOC) and microbial biomass carbon (MBC) in organic manure plus inorganic fertilizer treatments (NP+S and NP+FYM) in 0-60 cm depth were increased by 64.9-91.9\%, 42.5-56.9\%, and 74.7-99.4\%, respectively, over the CK treatment. Accumulation of crop residues and organic matter in the surface layer under conservation tillage creates favourable feeding conditions and also provides physical protection to various soil organisms, thereby increasing their abundance as well as diversity. 


\section{Introduction}

Permafrost soils currently store more than twice of the amount of carbon (C) in the atmosphere (Tarnocai et al., 2009), and recent climate warming is expected to accelerate the decomposition rate of soil organic matter (SOM) stored in permafrost soils (Zimov et al., 2006). Labile soil organic matter (SOM) fractions such as dissolved organic carbon (DOC), light-fraction carbon (LFC) and nitrogen (LFN), and the microbial biomass carbon (MBC) and nitrogen (MBN), were characterized by their fast turnover rates (Haynes, 2005), are especially important in the decomposition and mineralization processes of the permafrost ecosystems because they are the main source of $\mathrm{C}$ released from soil to the atmosphere, and their responses to climate change will be a very important factor determining the future soil C balance (Dutta $e t$ al., 2006).

Zhang et al., (2016) revealed that tillage practices and crop residue management significantly influenced the PON content across the soil profile [Fig. 1a]. Differences in PON in favour of NTR were particularly noticeable in the $0-10 \mathrm{~cm}$ soil layers with differences up 40 to $50 \%$, whereas the difference was only $5.1 \%$ in the $10-20 \mathrm{~cm}$ layer. No significant differences were observed below $20 \mathrm{~cm}$. The MBN content varied significantly from 1.2 to $37.8 \mathrm{mg} \mathrm{kg}^{-1}$ in the NTR treatment and from 2.9 to $17.5 \mathrm{mg}$ $\mathrm{kg}^{-1}$ in the CT treatment at the various soil depths [Fig. 1a]. Compared with CT, the MBN content in the NTR treatment was $116 \%$ and $108 \%$ higher at depths of $0-5 \mathrm{~cm}$ and 5-10 $\mathrm{cm}$, respectively. However, no significant differences in the MBN contents were observed between the CT and NTR treatments at depths below $10 \mathrm{~cm}$. The WEON contents were $69.4 \%$ and $44.9 \%$ higher under NTR than under CT at depths of $0-5 \mathrm{~cm}$ and 5-10 cm, respectively [Fig. 1a]. Sainju et al., (2012) also observed a significant increase in the PON content, mainly in the surface soil, when no-tillage was practiced. MBN is an important biological indicator of soil quality. In addition, soil MBN is more sensitive than soil MBC regarding its response to changes in soil management. Greater soil MBN contents are favoured in the absence of soil tillage, which reinforces our previous observations of the importance of MBN when explaining the benefits of NT (Hungria et al., 2009).

Shang et al., (2016) reported that the LFC and LFN concentrations [Fig. 1b] in the ASM and AM soils both reached their highest values in November 2013. The highest LFC and LFN concentrations in the AS soil both occurred in May 2013, versus September or December 2013 for the AD soils. The LFN concentration was generally highest in the ASM soil (0.6 to $1.7 \mathrm{~g} \mathrm{~kg}^{-1}$ soil), followed by the AM (0.3 to $0.9 \mathrm{~g} \mathrm{~kg}^{-1}$ soil) and AS soils (0.07 to $0.20 \mathrm{~g}$ $\mathrm{kg}^{-1}$ soil), with the lowest value in the AD soil (0.02 to $0.12 \mathrm{~g} \mathrm{~kg}^{-1}$ soil) [Fig. 1b].

Shang et al., (2015) also found that the highest MBC and MBN concentrations in the ASM, AM, and AS soils [Fig. 1c] all occurred in the summer, although the ASM soil showed a second peak in October or November 2013. The MBC and MBN concentrations tended to decrease in the autumn samples in the other three soils. The MBC and MBN concentrations in all four vegetation types tended to increase from February to March 2014 [Fig. 1c]. Among the different vegetation types, the MBC and MBN showed similar patterns with those of DOC and light fractions. The highest MBC (179.6 to $850.8 \mathrm{mg} \mathrm{kg}^{-1}$ soil) and MBN (36.1 to $279.6 \mathrm{mg} \mathrm{kg}^{-1}$ soil) concentrations were recorded in ASM soil, followed by the AM soil (104.9 to $494.9 \mathrm{mg}$ $\mathrm{kg}^{-1}$ soil for MBC, 6.8 to $109.1 \mathrm{mg} \mathrm{kg}^{-1}$ soil for $\mathrm{MBN}$ ).For the AS soil, the MBC and MBN concentrations ranged from 83.8 to $386.9 \mathrm{mg}$ $\mathrm{kg}^{-1}$ soil, and 3.0 to $32.1 \mathrm{mg} \mathrm{kg}{ }^{-1}$ soil, 
respectively. The AD soil had the lowest MBC (33.3 to $192.2 \mathrm{mg} \mathrm{kg}^{-1}$ soil) and MBN concentrations (0.4 to $38.6 \mathrm{mg} \mathrm{kg}^{-1}$ soil) [Fig. $1 \mathrm{c}]$.

Soil DOC concentrations in the ASM, AM, and AD soils [Fig.1d] varied highly but tended to increase from April to May 2013, then increased again from July to August 2013 and from November to December 2013. During the entire sampling period the DOC concentration was highest in the ASM soil (56.4 to $137.5 \mathrm{mg} \mathrm{kg}^{-1}$ soil), followed by the AM (42.5 to $99.7 \mathrm{mg} \mathrm{kg}^{-1}$ soil) and AS soils (18.5 to $64.6 \mathrm{mg} \mathrm{kg}^{-1}$ soil), with the lowest value in the $\mathrm{AD}$ soil $\left(12.3\right.$ to $56.9 \mathrm{mg} \mathrm{kg}^{-1}$ soil) [Fig.1d].

Conforti et al., (2016) observed that the maximum value $\left(214.5 \mathrm{Mg} \mathrm{ha}^{-1}\right)$ of SOC stock was observed in the A horizons accounting for about $30 \%$ of the estimated total SOC stock along soil profile [Fig.2a]. The significant lowest values were recorded in the organic horizon, which stored approximately $2 \%$ of total SOC stock. Vertical distribution of SOC stock [Fig. 2a] highlighted that even though there was less variability in SOC stock across A-Bw horizons, a significant decrease with depth was observed towards $\mathrm{BC}$ and especially $\mathrm{Cr}$ layers. The results revealed that the sampling thickness of $20 \mathrm{~cm}$ for Cr layers can be considered reliable because of the above quoted decreasing trend of SOC stock in depth. This behaviour is consistent with the evidence that N96\% of SOC was stored in the overlying soil horizons. In addition, a similar decreasing trend of the weathering degree of the parent rock downprofile suggests a possible corresponding decrease in the storage capacity of SOC.

Ma et al., (2016) also found that tillage TOC declined with increasing depth in all three treatments; the levels of TOC in [Fig. 2b] are clearly superior in PRB compared to TT and
FB. At $0-5 \mathrm{~cm}$ and $5-10 \mathrm{~cm}$ depths in PRB, the concentration of TOC was significantly higher than the corresponding depths in FB and TT (PRB > FB > TT). However, at 10-20 and $20-40 \mathrm{~cm}$, no significant differences were observed in TOC concentration between treatments. At $40-60 \mathrm{~cm}$,TT tillage had the highest TOC concentration $\left(5.5 \mathrm{gkg}^{-1}\right)$ which differed significantly from FB $\left(4.6 \mathrm{gkg}^{-1}\right)$; the trend in TOC concentration was TT >PRB $>$ FB. At $60-90 \mathrm{~cm}$, no statistical differences appeared between tillage treatments [Fig. 2b]. Brevik et al., (2002) reported a significant reduction in SOC below the compacted soil, and soil compaction weakened root growth and nutrient movement (Guo et al., 2012). Consequently, TOC contents were highest in the PRB treatment followed by FB and then TT. TOC contents at $40-60 \mathrm{~cm}$ under TT were significantly higher than FB because tillage increased SOM in the lower soil layers.

Ma et al., (2016) reported that the stratification ratio (SR) of TOC was significantly higher under PRB and FB than under TT at all depth ratios [Fig. 2c]. SR was calculated from the TOC concentration at $0-5$ $\mathrm{cm}$ divided by that at 5-10, $10-20$ and 20-40, 40-60 and 60-90 cm. Up to $40 \mathrm{~cm}$ depth, SR did not reach the threshold value of 2 . At depths greater than $40 \mathrm{~cm}$, SR was >2 for PRB and FB but not for TT. The higher SR of TOC for $\mathrm{PRB}$ and $\mathrm{FB}$ suggests that conservation tillage increased TOC concentration at the soil surface $(0-5 \mathrm{~cm})$ [Fig. 2c]. Franzluebbers (2002) suggested that the SR of SOC may be a better indicator of soil health than SOC because surface SOM is absolutely essential to erosion control, water and nutrient conservation. Differences in SMBC were limited to the surface layers $(0-5$ and $5-10$ $\mathrm{cm}$ ) in the PRB treatment [Fig. 2d]. There was a significant reduction in SMBC content with depth in all treatments. SMBC in the PRB treatment increased by $19.8 \%, 26.2 \%, 10.3 \%$, $27.7 \%, 10 \%$ and $9 \%$ at $0-5,5-10,10-20,20$ 
40, 40-60 and 60-90 cm depths, respectively, when compared with the TT treatment. The mean SMBC of the PRB treatment was $14 \%$ higher than that in the TT treatment [Fig. 2d]. The continuous no tillage with high standingstubbles and crop residue coverage on the soil surface in the PRB and FB treatments would create favourable environments for the cycling of $\mathrm{C}$ and formation of macro-aggregates. Moreover, POC acts as a cementing agent to stabilize macro-aggregates and protect particulate organic matter, thereby increasing TOC contents (Naresh et al., 2017).

Ghosh et al., (2016) revealed that at $25{ }^{0} \mathrm{C}$, plots under unfertilized control, $\mathrm{N}$ and NP treatments had similar $\mathrm{Ct}$ values up to Day 10 after incubation. On Days 17 and 24 after incubation, NP plots had significantly higher $\mathrm{Ct}$ values compared with unfertilized control and $\mathrm{N}$ plots [Fig. 3a]. The $\mathrm{Ct}$ values of these plots throughout the experimentation period were significantly less than NPK, $150 \%$ NPK, $\mathrm{NPK}+\mathrm{FYM}$, and NPK + L plots. However, those plots had similar $\mathrm{Ct}$ values. At $35{ }^{0} \mathrm{C}$, a slightly different trend was observed [Fig. 3a]. From Day 7 after incubation onwards, NP plots had significantly higher $\mathrm{Ct}$ values compared with unfertilized control and $\mathrm{N}$ plots. NP and $150 \%$ NPK plots also had similar $\mathrm{Ct}$ values. However, there was a sudden increase in $\mathrm{C}$ mineralization rate in the plots under $150 \%$ NPK from the Day 10 onwards [Fig. 3a]. Both NPK and 150\% NPK treated plots had lower $\mathrm{Ct}$ values than NPK + FYM and NPK + L plots up to Day 10. From Day 10 onwards, NPK, 150\% NPK, NPK + FYM, and NPK + L plots had similar Ct values [Fig. 3a]. SOC mineralization rates in the $15-30 \mathrm{~cm}$ soil layer steadily increased in all treatments from Day 4-after incubation onwards at both temperatures [Fig. 3a]. Fertilization had significant impacts on $\mathrm{Ct}$ values on all sampling days, with $\mathrm{NPK}+\mathrm{L}$ and NPK + FYM treated plots having similar $\mathrm{Ct}$ values, and $\mathrm{Ct}$ values of these treatments were significantly higher than other treatments [Fig. 3a].

Wang et al., (2015) also concluded that the straw burial depth significantly increased the TOC and LOC in different soil layers [Fig. $3 b]$. For the $0-10 \mathrm{~cm}$ and $10-20 \mathrm{~cm}$ soil layers, DB-SR-20 had a higher TOC than the other straw burial depth treatments; DB-SR-30 had a higher LOC content in the $0-10 \mathrm{~cm}$ soil layer, while DB-SR-20 had a higher LOC content in the $10-20 \mathrm{~cm}$ soil layer than the other burial depth treatments. For the 20-30 $\mathrm{cm}$ soil layer, DB-SR-30 had a higher TOC content but DB-SR-40 had a higher LOC content than the other burial depth treatments. For the $30-40 \mathrm{~cm}$ and $40-50 \mathrm{~cm}$ soil layers, DB-SR-40 showed significantly higher TOC and LOC contents [Fig. 3b]. The TOC var (\%) and LOC var (\%) under different burial amounts in different years [Fig. 3c], the DB SR-T showed higher TOC var $(\%)$ and LOC var (\%) levels than the other burial amount treatments in the $10 \mathrm{~cm}$ soil layers above the straw. The TOC var (\%) showed the highest variation among the different burial amount treatments in the $10 \mathrm{~cm}$ soil layer below the straw; however, the DB-SR-T showed a higher LOC increase when the DB-SR-TW had negative effects on the LOC [Fig. 3c]. (Bhattacharyya et al., 2012; Naresh et al., 2018) suggested that returning rice straw to fields could increase the SOC content. Moreover, higher TOC levels in the soil layers above and below the straw layer, and reflected the carbon sequestration potential of the straw returning method. This might be due to the following reasons: firstly, the straw was condensed in a limited soil space and submerged in water during the rice season, which meant that the buried straw was under a reduced environment. This would result in the decomposition of the straw being slowed down and therefore the SOC's mineralization rate (Wu et al., 2010). Secondly, some of the carbon-containing compounds in the straw 
were decomposed, mineralized and released as $\mathrm{CO}_{2}$ into the atmosphere, while others were transformed into humus that accumulated in the soil, which is the main source of soil organic matter (Stockmann et al., 2013).

Kuhn et al., (2016) also found that the benefit of NT compared to CT on the changes of SOC stocks varied across different soil depths [Fig. 4a]. In topsoil layers (above $20 \mathrm{~cm}$ ), NT in general had greater SOC stocks than CT [Fig. 4a], but the benefit tended to decline with soil depths, and even turned to be negative in soil layers deeper than $20 \mathrm{~cm}$ [Fig. 4a]. In addition, in each soil layer, except for the top $5 \mathrm{~cm}$, the total SOC stocks generally declined with the number of years after NT adoption [Fig. 4a].

Dhaliwal et al., (2018) revealed that the mean SOC concentration decreased with the size of the dry stable aggregates (DSA) and water stable aggregates (WSA). In DSA, the mean SOC concentration was 58.06 and $24.2 \%$ higher in large and small macro-aggregates than in micro-aggregates respectively; in WSA it was 295.6 and $226.08 \%$ higher in large and small macro-aggregates than in micro-aggregates respectively in surface soil layer [Fig. 4b]. The mean SOC concentration in surface soil was higher in DSA $(0.79 \%)$ and WSA $(0.63 \%)$ as compared to bulk soil $(0.52 \%)$ [Fig. 4b]. Lal (2004a) found that the rate of SOC increase attains the maximum effect 5- 20 years after adoption of management practices aimed at increasing SOC stocks. Tang and Nan (2012) estimated that no-tillage and high residue incorporation techniques have the potential to increase SOC sequestration by up to $0.4 \mathrm{t} \mathrm{ha}^{-1} \mathrm{yr}^{-1}$. However, with reduced or no-tillage, less litter is moved from the soil surface deeper into soil profile. Hence, the increased SOC concentration is very likely to be constrained to topsoil layers that are still mixed by direct seeding (Liu et $a l ., 2014)$, and balanced out by a decline in the soil profile not subject to tillage anymore. $\mathrm{Yu}$ et al., (2013) also found that the simulations, including changes in climate and agricultural management, suggest that aggregate national mineral SOC stocks will continuously increase at varying rates from 2011 to 2050 across all scenarios [Fig. 4c]. However, trends in carbon sequestration vary among the scenarios. We found a decrease in carbon sequestration under S0, a slight increase under S1 and a significant increase under $\mathrm{S} 2$. The carbon sequestration rates under $\mathrm{S} 0, \mathrm{~S} 1$ and $\mathrm{S} 2$ are estimated to be

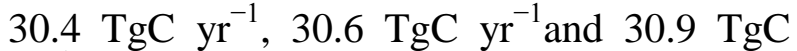
$\mathrm{yr}^{-1}$, respectively, by 2011. By 2050, carbon

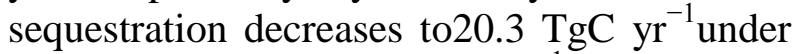
S0 but increases to $50.5 \mathrm{TgC} \mathrm{yr}^{-1}$ under $\mathrm{S} 1$ and

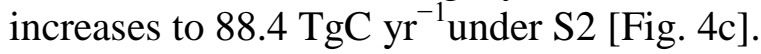

Deng et al., (2016) concluded that the soil OC stocks and OC sequestration in the surface 20 $\mathrm{cm}$ of soils were significantly increased along with the vegetation restoration since land-use change [Fig. 5a]. In the first 10 years, soil OC stocks showed non-significant increasing trends and then (>30 year) significantly increased compared to the initial level [Fig. 5a]. Soil OC sequestrations significantly increased after grassland stages (S1) and herbage (S2)] [Fig. 5a]. Soil OC sequestration achieved $5.94 \mathrm{~kg} \mathrm{C} \mathrm{m}^{-2}$ after 160 years of vegetation restoration since land-use change [Fig. 5a]. Vegetation restoration facilitated SOC accumulation from biomass input (Tang et al., 2010). Vegetation biomass resulting from aboveground leaf litter and belowground roots is the main source of organic matter input into the soil (Zhao et al., 2015); (2) vegetation restoration probably contributed to the formation of stable soil aggregates (An et al., 2010), ; and (3) the lower SOC concentrations of farmland under conventional tillage may be due to OC loss resulting from soil erosion, higher organic matter decomposition associated with aggregate disruption and/or OC input reduction caused by continuous removal of crop residues (Saha 
et al., 2014). Kätterer et al., (2014) observed that in the compost-amended treatment the mean increase in SOC was $1.48 \mathrm{Mg} \mathrm{C}$ ha $^{-1} \mathrm{yr}^{-1}$ to $40.1 \quad \mathrm{~cm}$ depth. Although differences in soil $\mathrm{C}$ concentration generally decreased with depth, the treatment effect was significant in all layers down to $40 \mathrm{~cm}$ depth according to analysis of variance [Fig. 5b].

Deng et al., (2016) reported that the soil OC decomposition rate was higher $(k=0.04)$ in the early stage $(\sim 10$ year $)$ after land-use change [Fig. 5c]. It significantly declined along with the vegetation restoration and soil OC decomposition rate showed a nonsignificant difference after 30 years of vegetation restoration. Similarly, the rate of new soil OC increase was also higher in the early stage ( 10 year) after land-use change [Fig. 5c]. The rate of new soil OC increase ranged from 109.17 to $41.88 \mathrm{~g} \mathrm{~m}^{-2}$ year $^{-1}$ in the early $(\sim 10$ year $)$ and later stages $(\sim 160$ year), respectively.

Meena et al., (2018) revealed that the WBC decrease in CL and BL was accompanied by mean increase in soil bulk density of $21 \%$ compared with FL [Fig. 6a]. The WBC and LOC concentrations from barren land, cultivated land, grass land and forest land significantly varied among the LUS and soil depth form $0-15,15-30$ and $30-45 \mathrm{~cm}$ soil depth [Fig. 6a]. The significantly highest WBC and LOC concentrations were observed in the top $0-15 \mathrm{~cm}$ depth and decreased with increase in depth. It was observed that FL showed highest WBC concentrations followed by GL, CL and BL of ecosystem. Significantly highest WBC (14.45 $\left.\mathrm{g} \mathrm{C} \mathrm{kg}^{-1}\right)$ was observed with FL followed by GL (12.54 $\left.\mathrm{g} \mathrm{C} \mathrm{kg}^{-1}\right), \mathrm{CL}$ (9.23 $\mathrm{g} \mathrm{C} \mathrm{kg}^{-1}$ ) and significantly lowest was recorded with the $\mathrm{BL}\left(6.26 \mathrm{~g} \mathrm{C} \mathrm{kg}^{-1}\right)$ in the top surface soil $0-15 \mathrm{~cm}$ depth [Fig. 6a]. However, among the soil depth the significantly higher WBC (10.62 $\left.\mathrm{g} \mathrm{C} \mathrm{kg}^{-1}\right)$ was noticed in the $0-15 \mathrm{~cm}$ soil depth followed by $15-30 \mathrm{~cm}$ soil depth $(8.78 \mathrm{~g} \mathrm{C}$ $\mathrm{kg}^{-1}$ ) and lowest was recorded with $30-45 \mathrm{~cm}$ soil depth (6.81 $\mathrm{g} \mathrm{C} \mathrm{kg}^{-1}$ ). Meanwhile, the cumulative effect of soil depth $(0-45 \mathrm{~cm})$ resulted $8.74 \mathrm{~g} \mathrm{C} \mathrm{kg}^{-1} \mathrm{WBC}$ under various land use systems [Fig. 6a]. The build-up of different carbon fractions in the natural plantation is mainly due to long-term additions of carbon through leaf litter. Nevertheless the soils of this plantation are never disturbed by tillage operations that are otherwise very frequently practiced in other cultivated soils (Brady and Weil, 2002). Significantly highest soil C-sequestration $\left(\sim 161 \mathrm{Mg} \mathrm{ha}^{-1}\right)$ was observed under the forest land followed by grass land ( $\left.\sim 134 \mathrm{Mg} \mathrm{ha}^{-1}\right)$, cultivated land ( $\left.92 \mathrm{Mg} \mathrm{ha}^{-1}\right)$ and significantly lowest was observed under the barren land ( 92 $\mathrm{Mg} \mathrm{ha}^{-1}$ ) in the 0-45 cm soil depth [Fig. 6b]. However, at $0-45 \mathrm{~cm}$ depth showed higher $(\sim 120 \mathrm{Mg}$ $\mathrm{ha}^{-1}$ ) soil C-sequestration in forest land. 0-45 $\mathrm{cm}$ soil depths had $\sim 62,66$ and $71 \%$ higher Csequestration as compared to $0-15,15-30$ and 30-45 cm depth, respectively. Soil Nsequestration significantly varied from 10.58 to $13.82 \mathrm{Mg} \mathrm{ha}^{-1}$ under forest to barren land use systems [Fig. 6b]. Moreover, in 0-45 cm soil depth, the $\mathrm{N}$-sequestration rate significantly higher (13.82 $\mathrm{Mg} \mathrm{ha}^{-1}$ ) under forest land, at par with grass land $(13.66 \mathrm{Mg}$ $\mathrm{ha}^{-1}$ ) followed by cultivated and barren land with 11.52 and $10.58 \mathrm{Mg} \mathrm{ha}^{-1}$, respectively. At $0-45 \mathrm{~cm}$ depth showed its significantly superiority with $12.39 \mathrm{Mg} \mathrm{ha}^{-1}$ followed by $0-$ $15 \mathrm{~cm}\left(4.41 \mathrm{Mg} \mathrm{ha}^{-1}\right), 15-30 \mathrm{~cm}(4.15 \mathrm{Mg}$ $\mathrm{ha}^{-1}$ ), however, significantly lowest soil Nsequestration $13.83 \mathrm{Mg} \mathrm{ha}^{-1}$ in the $30-45 \mathrm{~cm}$ soil depth [Fig. 6b].

At the $0-15 \mathrm{~cm}$ depth, forest land contained significantly higher TC and TN concentrations than grass, cultivated and barren land. There were significant differences among soil depths in TC and TN concentrations. The TC significantly highest $\left(22.92 \mathrm{~g} \mathrm{C} \mathrm{kg}^{-1}\right)$ was observed in the $0-15 \mathrm{~cm}$ depth followed by 
15-30 cm (19.94 $\left.\mathrm{g} \mathrm{C} \mathrm{kg}^{-1}\right)$ and lowest (17.01 $\mathrm{g} \mathrm{C} \mathrm{kg}^{-1}$ ) was recorded with $30-45 \mathrm{~cm}$ soil depth [Fig. 6c]. The highest TN concentration $\left(2.23 \mathrm{~g} \mathrm{~N} \mathrm{~kg}^{-1}\right)$ was recorded in $0-15 \mathrm{~cm}$ soil depth followed by $15-30$ and $30-45 \mathrm{~cm}$ soil depth with 2.06 and $1.89 \mathrm{~g} \mathrm{~N} \mathrm{~kg}^{-1}$, respectively. In addition, the cultivated land contained significantly higher TC (15.39 g C $\left.\mathrm{kg}^{-1}\right)$ and $\mathrm{TN}\left(1.91 \mathrm{~g} \mathrm{~N} \mathrm{~kg}^{-1}\right)$ as compared to barren land TC $\left(15.18 \mathrm{~g} \mathrm{C} \mathrm{kg}^{-1}\right)$ and TN $(1.75$

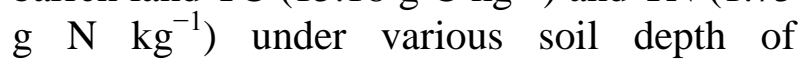
ecosystem [Fig. 6c]. In the depth of $0-45 \mathrm{~cm}$, the TC and TN concentrations significantly greater under forest land than grass land, cultivated and barren land. Averaged across the depth, the TC concentrations of the 0-45 $\mathrm{cm}$ depth were 26.93, 22.33, 15.39 and 15.18 g $\mathrm{C} \mathrm{kg}^{-1}(\mathrm{p}<0.05)$, while the $\mathrm{TN}$ concentrations were 2.31, 2.28, 1.91 and 1.75 $\mathrm{g} \mathrm{N} \mathrm{kg}^{-1}$ for forest land, grassland, cultivated and barren land use systems, respectively [Fig. 6c]. The TC: TN ratios under different land use systems significantly varied from 7.90 to 11.78 in the $0-45 \mathrm{~cm}$ layer (Fig. $3 \mathrm{c}$ ). The TC: TN ratios significantly differed among soil depth in the all four LUS. However, the TC: TN ratios significantly higher under forest land and grass land than cultivated and barren land in $0-45 \mathrm{~cm}$ depth layer [Fig. 6c]. The TC: TN ratios of cultivated land were lowest in 15-30 and 30-45 cm depth. While, mean TC: TN ratios were 8.49, 7.90, 9.72 and 11.78 for barren, cultivated, grass and forest land, respectively. However, the variation in TC: $\mathrm{TN}$ ratios may be due to difference in $\mathrm{OM}$ compositions among land uses. OM accounted for greater proportion of TC and TN under grass and forest land than cultivated and barren land in the $0-15 \mathrm{~cm}$ depth [Fig. 6c]. Lack of stratification under cultivated land was mainly due to incorporation of crop residues into plow layer by tillage, which caused to accelerate mineralization by increasing contact of crop residues and SOC with atmosphere (Ghosh et al., 2016).
Poeplau et al., (2017) also found that the difference in NPP between the unfertilised treatments and the high $\mathrm{N}$ rates increased only in the first decade and remained relatively constant thereafter. However, the SOC stocks in both the RR and RI treatments were not influenced by $\mathrm{N}$ level [Fig. 7a], which did not interact with residue management. The difference in SOC stock between RI and RR at the highest $\mathrm{N}$ rate $(240 \mathrm{~N})$ was $2.9 \mathrm{Mgha}^{-1}$, while the difference at the lowest $\mathrm{N}$ level $(0 \mathrm{~N})$ was $3.1 \mathrm{Mgha}^{-1}$, despite the difference in annual $\mathrm{C}$ input between RI and RR for these two $\mathrm{N}$ extremes being $0.43 \mathrm{Mgha}^{-1}$ year $^{-1}$ [Fig. 7a]. Naresh et al., (2018) estimated that the coarse fractions SA and POM and the liquid DOC fraction contributed only $4 \%, 2.3 \%$ and $1.7 \%$ respectively to the total SOC stock. Furthermore, $93 \%$ of the total surplus of SOC due to 40 years of residue incorporation was found in the SC fraction. Within the SC fraction, the greatest change in SOC stock occurred in the more active SC-rSOC fraction, while the more passive rSOC on average did not change at all [Fig. 7b].

Chen et al., (2014) concluded that the greater OPOM-C values were observed in soils from Med than from conv systems, and OPOM-C stocks declined significantly in the Med systems in both soils and Long system in the IA soil during 0-180 days of the incubation. During the last 180-330 days, the OPOM stocks remained unchanged in all systems in the IAsoil and increased slightly in the med system in the MD soil [Fig. 7c]. By removing loose-POM, which contains organic residues and roots that are not well decomposed or bound to minerals, and resolved differences among cropping systems treatments that were obscured by the presence of the more labile residues, suggesting stronger predictive power of OPOM than total POM [Fig. 7c]. Lazicki, (2011) asserted decay rates in the IAsoil must vary among systems to maintain similar levels of SOC despite differences in $\mathrm{C}$ input levels. 
The highest changes in total organic $\mathrm{C}$, total $\mathrm{N}$, and $\mathrm{C}$ : $\mathrm{N}$ ratio, labile and recalcitrant $\mathrm{C}$ occurred in the $0-40 \mathrm{~cm}$ depth. In general, soil organic matter decreased as depth increased. At $0-20 \mathrm{~cm}$ layer, FS tended to has less total organic $\mathrm{C}$, recalcitrant $\mathrm{C}$ and bulk density when compared to the ACS. Thomazini et al., (2015) also found that the total organic C observed to be higher in NR and ACS at 0-5 $\mathrm{cm}$ layer, showing similar results up to $40 \mathrm{~cm}$ depth. A similar trend was observed for labile and recalcitrant $\mathrm{C}$. Total $\mathrm{N}$ is leaning to be higher under the NR. Total $\mathrm{N}$ tended to be similar in the ACS and NR up to $20 \mathrm{~cm}$ depth. Minor variations of total organic $\mathrm{C}$ ranged from 6.31 to $7.65 \mathrm{~g} \mathrm{~kg}^{-1}$ and occurred in the FS. Bulk density tended to decrease in soil depth, and NR tended to present the lowest values. Bulk density was observed to be higher in the FS system $(1.53 \mathrm{~g} \mathrm{~cm}-3$ at 5-20 $\mathrm{cm}$ layer), and lower in the NR system. Bulk density tended to be lower in the ACS system $\left(1.30 \mathrm{~g} \mathrm{~cm}^{-3}\right.$ at $5-20 \mathrm{~cm}$ layer $)$ when compared to FS [Fig. 8a]. Soto-Pinto et al., (2010) indicate that the dry season, with low moisture and soil temperature decreases the rates of microbial biomass activity. The trend of total organic C near-surface in NR and ACS when compared to FS is due to the continuous input of organic material provided by litter fall. Conforti et al., (2018) reported that the soil BD varied between $0.23 \mathrm{~g} \mathrm{~cm}^{-3}$ and $1.66 \mathrm{~g}$ $\mathrm{cm}^{-3}$ and a tendency to increase gradually with depth [Fig. 8b]. Significant differences of BD values in consecutive horizons were observed for $\mathrm{AB}-\mathrm{Bw}$ and $\mathrm{BC}-\mathrm{Cr}$ horizons [Fig. 8b]. SOC concentration in $\mathrm{O}$ horizons ranged between 217.0 and $369.8 \mathrm{~g} \mathrm{~kg}^{-1}$, with a mean value of $284.9 \mathrm{~g} \mathrm{~kg}^{-1}$ and, as expected, it was statistically higher than mineral horizons [Fig. 8b]. High concentration of SOC in the organic horizon was related to the abundance of beech litter fall (Guckland et al., 2009) and the continuous supply of carbon provided by the decomposition of plant detritus and roots. Such phenomena are generally favoured by high precipitation which leads to low rates of litter decomposition and therefore SOC accumulation (Guckland et al., 2009). Zhang et al., (2018) concluded that the plant C: N ratio may follow an order: native species $(\sim 31)$ $<$ crops $(\sim 53)$, and aboveground tissues ( 32) $<$ belowground tissues ( $\sim 52)$. Soil C: $\mathrm{N}$ ratio in native land (9.9) is closed to that in cropland [Fig. 8c].

Cui et al., (2014) found that the contribution of physically stabilized carbon (i.e. microaggregate-occluded particulate organic carbon, iPOM) to SOC kept around $16 \%$ in croplands even when micro-aggregate contents increased from $8.83 \%$ to $30.52 \%$ between 16 and 500 years. The iPOM fraction was not closely related to micro-aggregate formation but to free coarse particulate organic matter, a carbon fraction indicative of inputs of plant materials. Consistently higher SOC density in paddy soils than in upland soils was observed along the chronosequence, which could be accounted for by higher contents of physical and chemical carbon fractions in paddy fields. The higher physically-stabilized carbon of paddy soils probably resulted from larger stubble return rather than from stronger soil aggregation given similar contents of microaggregates between the two cropland types. Notably, in both paddy and upland soils, carbon concentrations of intra-microaggregate silt/clay particles were consistently higher than those of free silt/clay particles. An implication was that despite the small proportion $(<20 \%$ here $)$ of physicallystabilized carbon to total SOC in croplands, soil aggregation could promote chemical SOC stabilization by creating intimate interactions between occluded carbon and soil minerals within aggregates [Fig. 9a].

Singh et al., (2015) revealed that the total carbon stock in the topsoil (equivalent to 200 $\mathrm{kg} \mathrm{m}^{-2}$ ) was slightly lower under reduced tillage $\left(5.0 \mathrm{~kg} \mathrm{~m}^{-2}\right)$ than under conventional 
tillage $\left(5.2 \mathrm{~kg} \mathrm{~m}^{-2}\right)$. Reduced tillage changed the soil composition by increasing the percentage of macro-aggregates and decreasing the percentage of microaggregates. There was no evidence of differences in the composition of the macroaggregates or carbon content in the macroaggregate-occluded fractions. However, due to the higher total amount of macro-aggregates in the soil, more carbon was bound to the macroaggregate-occluded micro-aggregates in reduced tillage [Fig. 9b]. Moreover, reduced tillage can improve clay soil structure, generally the chances to increase topsoil carbon sequestration by reduced tillage or straw management practices appear limited in cereal monoculture systems [Fig. 9b].

Juan et al., (2018) observed that the decomposition process of OMs could be divided into three stages, 0-90 days for a "quick decomposition period", 90-180 days for a "slow decomposition period", and 180540 days for a "stable decomposition period" [Fig.9c]. In 90 days, decomposition rate of OMs was over $70 \%$. In 540 days, residual quantities of CM, SM and MS decreased to $5.69,6.11$, and $6.53 \mathrm{~g}$ from the initial $20 \mathrm{~g}$, whereas those of MR, FG, and TL decreased to $8.05,8.84$, and $10.32 \mathrm{~g}$, respectively. Moreover, the decomposition rates of $\mathrm{CM}$, SM, and MS (71.55\%, 68.16\%, and 68.21\%) were higher than those of MR, FG, and TL (58.64\%, 55.28\%, and 47.95\%), respectively [Fig. 9c]. Gao et al., (2010) and Liang et al., (2011) showed that water soluble organic carbon (WOC) contents in soil after application of animal manures were higher than those of straw. The LC contents in soil after the applications of CM and SM were significantly higher than those of other OMs, and followed by MS, whereas that of TL was the lowest.

Juan et al., (2018) revealed that the trends of quantities of carbon released from OMs were first quickly increased and then tended to stable in decomposition process [Fig. 9d]. Quantity of carbon released from MS was higher than those of other OMs in each period. In 90 days, quantities of carbon released from OMs were over 65\%. In 540 days, quantities of carbon released from MS, TL, MR, FG, SM, and CM were 6.38, 4.85, 4.71, 4.64, 4.37, and $3.80 \mathrm{~g}$, respectively [Fig. 9d]. Singh et al., (2009), who suggested that the quality of OMs was an important factor on agricultural soil carbon changes besides the amount of injected carbon. However, the amount of carbon inputted was equivalent in different $\mathrm{OMs}$ treatments. Therefore, the variation of SOC fractions mainly depended on the nature of OMs.

Naresh et al., (2017) reported that after 15 years, $\mathrm{T}_{3}$ treatment resulted in significantly increased $66.1 \%, 50.9 \%, 38.3 \%$ and $32 \%$ LFOC, PON, LFON and POC, over $\mathrm{T}_{7}$ treatment and WSC $39.6 \%$ in surface soil and $37.4 \%$ in subsurface soil. Out of the four C fractions, LFOC was the most sensitive indicator of changes in TOC induced by the soil tillage and nutrient management practices [Table 1]. LFOC were also significantly higher following the treatments including organic amendment than following applications solely of chemical fertilizers, except that the $\mathrm{F}_{5}, \mathrm{~F}_{6}$ and $\mathrm{F}_{7}$ treatments resulted in similar LFOC contents. Application solely of chemical fertilizers had no significant effects on LFOC and LFON fractions compared with unfertilized control plots. Nevertheless, application of $\mathrm{F}_{5}$ or $\mathrm{F}_{6}$ significantly increased contents of POC relative to $\mathrm{F}_{1}$ (by $49.6 \%$ and $63.4 \%$ ), respectively.

Sheng et al., (2015) also found that the stocks associated with the different LOC fractions in topsoil and subsoil responded differently to land use changes. POC decreased by $15 \%$, $38 \%$, and $33 \%$ at $0 \mathrm{e} 20 \mathrm{~cm}$ depth, and by $10 \%$, 
$12 \%$, and $18 \%$ at $20 \mathrm{e} 100 \mathrm{~cm}$ depth following natural forest conversion to plantation, orchard, and sloping tillage, respectively [Fig. 10a]. Regarding the different POC components, only fPOC stock in $0 \mathrm{e} 20 \mathrm{~cm}$ topsoil decreased by $21 \%, 53 \%$, and $51 \%$ after natural forest conversion to plantation, orchard, and sloping tillage, respectively [Fig. 10a]. This implied that the reduction of POC stock after land use change mainly resulted from the loss of topsoil fPOC, which, consequently, could be used as a sensitive indicator to detect SOC changes. Noticeably, fPOC stock in subsoil below $40 \mathrm{~cm}$ increased by $11 \mathrm{e} 74 \%$ following the land use change, indicating that changes in POC fractions in subsoil may follow the opposite direction to those in topsoil [Fig. 10a].

Loss of LFOC occurred not only in topsoil, but also in subsoil below $20 \mathrm{~cm}$ following land use change [Fig. 10b]. The topsoil showed a greater reduction in LFOC stock than did subsoil following the conversion of natural forest to orchard and sloping tillage. LFOC appeared to be more sensitive to land use changes than SOC both in top and subsoil [Fig. 10b]. The decrease in ROC stock through the soil depth profile following land use change was smaller than that of LFOC [Fig. 10b].

The DOC stock in the topsoil decreased by $29 \%$ and $78 \%$ following the conversion of natural forest to plantation and orchard, respectively, and subsoil DOC stocks decreased even more dramatically following land use change [Fig. 10b]. MBC stock decline was more pronounced in topsoil (49e86\%) than in subsoil (21e61\%) following land use change. DOC and $\mathrm{MBC}$ were the most sensitive indicators to land use change [Fig. 10b]. However, the sensitivity of LOC fractions to land use change depends on soil depth. In topsoil, fPOC, LFOC, DOC and MBC stocks were more sensitive to land use change than was SOC. In subsoil, on the other hand, only LFOC and DOC are sensitive enough to represent useful indicators of SOC changes. Similar to POC stocks and those of its different components, MBC in subsoil below $40 \mathrm{~cm}$ can increase after land conversion [Fig. 10b], indicating that changes of LOC fractions may follow opposite patterns to those in topsoil. In another example, soil $\mathrm{C}$ accumulation was almost entirely from LFOC in topsoil $(0-7.5 \mathrm{~cm})$, and $\mathrm{C}$ loss was mainly from $\mathrm{C}$ fractions associated with silt and claysize particles in the subsoil $(35-60 \mathrm{~cm}) 48$ years after the conversion of old fields into secondary forest (Mobley et al., 2015). In the topsoil, the ratios $\mathrm{PPOC}$, LFOC, and MBC to SOC decreased, while those of ROC and cPOC increased following land use change [Fig. 10b]. In subsoil, only the ratio of DOC to SOC decreased, the ratios POC, PPOC and ROC to SOC increased, and those of LFOC and $\mathrm{MBC}$ remained constant following land use change. In the topsoil, ratios fPOC, LFOC, DOC and MBC to SOC were more sensitive to conversion from natural forest to sloping tillage than SOC [Fig. 10b].

Zhu et al., (2014) reported that the soil MBN was $72 \%$ higher in the orchard and $75 \%$ higher in the grassland than in the cropland [Fig. 10c]. As a consequence, the MBN/total $\mathrm{N}$ was $53 \%$ and $46 \%$ higher in the orchard and grassland, respectively than in the cropland [Fig. 10c]. In the slope, the total $\mathrm{N}$ contents in soils with grassland, shrub land, and woodland were respectively $32 \%, 90 \%$, and $55 \%$ higher than those in the cropland $\left(1.18 \mathrm{t} \mathrm{ha}^{-1}\right)$, [Fig. 10c]. Both soil total $\mathrm{N}$ and MBN were similar between the cropland and the orchard. The $\mathrm{MBN} /$ total $\mathrm{N}$ in grassland, shrub land, and woodland, ranging from $4.36 \%$ to $4.56 \%$, was $35 \%$ to $41 \%$ larger than that $(3.23 \%)$ in the cropland [Fig. 10c]. In the gully, soil total $\mathrm{N}$ contents were $17 \%, 39 \%$, and $23 \%$ higher in the grassland, shrub-land, and woodland, respectively than in the cropland $\left(1.80 \mathrm{tha}^{-1}\right)$, 
[Fig. 10c]. Similar increases, ranging from $53 \%$ to $108 \%$ were obtained for MBN [Fig. 10c]. The MBN/total $\mathrm{N}$ ratios in the grassland, shrub-land, and woodland with a narrow range of $4.06 \%$ to $4.43 \%$, were $16 \%$ to $26 \%$ larger than that $(3.51 \%)$ in cropland [Fig. 10c].

Zhao et al., (2014) concluded that the contents of SOC, TN, POC and LOC responded differently as the change of soil depth [Fig. 11a]. In all land use types, contents of SOC, $\mathrm{TN}, \mathrm{POC}$ and LOC in top soil $(0-10 \mathrm{~cm})$ were $3.26-7.86$ g.kg ${ }^{-1}$ 0.39-0.72 g.kg ${ }^{-1}, 0.65-1.31$ g. $\mathrm{kg}^{-1}$ and $0.76-1.07$ g. $\mathrm{kg}^{-1}$, respectively, which were significantly higher than other soil layers. The contents of SOC, TN, POC and LOC decreased significantly in soil depth of $10-40 \mathrm{~cm}$ while the decreases trended to be flatter in subsoil $(40-100 \mathrm{~cm})$. Additionally, the differences in contents of SOC, TN, POC and LOC in deep subsoil $(100-200 \mathrm{~cm})$ were negligible. Vegetation can greatly influence soil quality, $\mathrm{C}$ and $\mathrm{N}$ cycling, and regional socioeconomic development (Fu et al., 2010). It is also reported that converting cropland into land with perennial vegetation would increase the SOC content (Groenendijk et al., 2002).

Duval et al., (2016) reported that the concentration of labile soil organic carbon $\left(\mathrm{POC}_{\mathrm{c}}\right.$ and $\left.\mathrm{POC}_{\mathrm{f}}\right)$ did not reflect any differences between the cover crops and $\mathrm{Ct}$ in 2008 at $0-20 \mathrm{~cm}$ [Fig. 11b]. The 3 years of Cinput by cover crops were insufficient to affect the most dynamic and labile fractions of SOM, despite $\mathrm{C}$-input differences among treatments. As from 2009, SOC increase by the cover crops was mainly due to higher $\mathrm{POC}_{\mathrm{c}}$ concentration [Fig. 11b]. In 2009 and 2011, the cover crops significantly enhanced $\mathrm{POC}_{\mathrm{c}}$ levels compared with Ct. Differences among cover crops were also found. In general, gramineous species showed higher $\mathrm{POC}_{c}$ concentration than $\mathrm{V}$. This difference among species may have been caused by the higher quality of the legume contribution (lower $\mathrm{C}$ : $\mathrm{N})$, which stimulated residue decomposition and thus had a direct influence on $\mathrm{POC}_{\mathrm{c}}$. Regarding the $\mathrm{Ct}$ treatment, $\mathrm{POC}_{\mathrm{c}}$ increased in the $\mathrm{W}, \mathrm{O}$ and $\mathrm{O}+\mathrm{V}$ treatments by 66 and $95 \%$ in 2009 - 2011, respectively, whereas in the V treatment, $\mathrm{POC}_{\mathrm{c}}$ rose by 33 and $49 \%$ for the same periods [Fig. 11b].

These results suggest that cover crops of gramineous species would enhance accumulation of more recalcitrant materials on the soil surface, thus promoting SOM increase. Also, larger residue amounts with a high concentration of soluble compounds and a low $\mathrm{C}$ : $\mathrm{N}$ ratio (vetch + soybean residues) would fuel microbial activity, stimulate decomposition and have a negative effect on organic fractions (Scherer-Lorenzen, 2008).

Wang et al., (2015) reported that on average, the SOC densities of the entire wheat-growing areas in each decade were $27( \pm 22 \%, 95 \%)$ $\mathrm{Mg} \mathrm{ha}^{-1}$ during the $1960 \mathrm{~s}, 24( \pm 17 \%) \mathrm{Mg} \mathrm{ha}^{-1}$ during the $1970 \mathrm{~s}, 22( \pm 18 \%) \mathrm{Mg} \mathrm{ha}^{-1}$ during the 1980s, $21( \pm 14 \%) \mathrm{Mg} \mathrm{ha}^{-1}$ during the $1990 \mathrm{~s}$, and $20( \pm 15 \%) \mathrm{Mg} \mathrm{ha}^{-1}$ during the 2000s, respectively [Fig. 11c]. Although average SOC densities decreased over the study period, the rate of SOC loss is declining, with more SOC lost in the first 30 years than in the last 20 years [Fig. 11c]. Averaging for each decade, the rate of SOC loss was estimated to be approximately $6.4,3.7,2.5$, 1.4 and $1.6 \mathrm{Tg} \mathrm{yr}^{-1}$ in the 1960s, 1970s, 1980s, 1990s and 2000s, respectively. Summing up the yearly changes in SOC over the period from 1960 to 2010, the loss of SOC in wheatgrowing areas was estimated to be $156 \mathrm{Tg} \mathrm{C}$, with a range from 86 to $222 \mathrm{Tg} \mathrm{C}$ at the $95 \%$ confidence level [Fig. 11c]. It is noteworthy that after the decline in the first few years, SOC seemed to reach a new, steady state in the mid-2000s, followed by a decrease in the following several years [Fig. 11c]. 
Fig.1 (a): Effects of long-term tillage practices on the depth distributions of particulate organic $\mathrm{N}$, microbial biomass $\mathrm{N}$ and water-extractable organic $\mathrm{N}$ [Source: Zhang et al., 2016] (b): Seasonal variations in soil LFC (A) and LFN (B) concentrations in the four vegetation types [Source: Shang et al., 2016] (c): Seasonal variations in soil MBC (A) and MBN (B) concentrations in the four vegetation types [Source: Shang et al., 2015] (d): Seasonal variations in soil DOC concentrations at depth of 0 to $10 \mathrm{~cm}$ in the four vegetation types [Source: Shang et al., 2015]

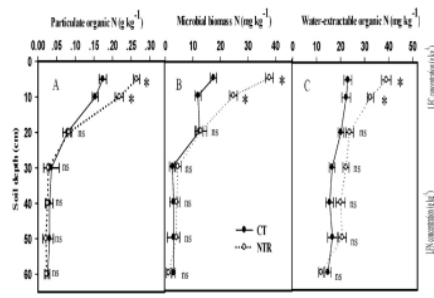

(a)

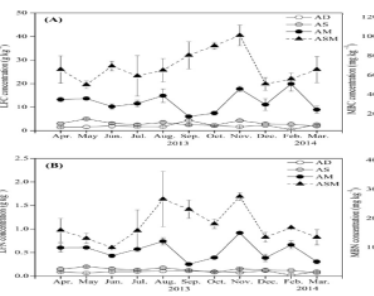

(b)

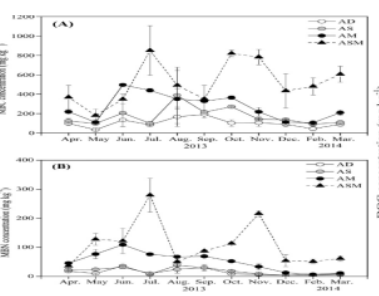

(c)

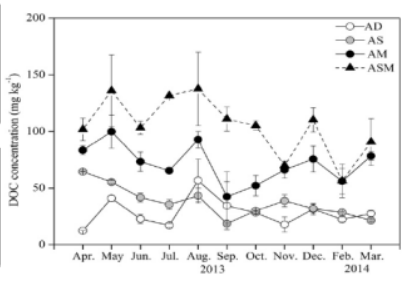

(d)

Fig.2 (a): SOC stock across soil profile and cumulative percentage of SOC stock within soil horizon [Source: Conforti et al., 2016] (b): Total organic carbon content with depth under traditional tillage (TT), flat raised bed with controlled traffic and zero tillage (FB) and permanent raised bed (PRB) [Source: Ma et al., 2016] (c): Total organic carbon stratification ratio in traditional tillage (TT), flat raised bed with controlled traffic and zero tillage (FB) and permanent raised bed (PRB) [Source: Brevik et al., 2002] (d): Microbial biomass carbon content with depth under traditional tillage (TT), flat raised bed with controlled traffic and zero tillage (FB) and permanent raised bed (PRB) [Source: Franzluebbers 2002]

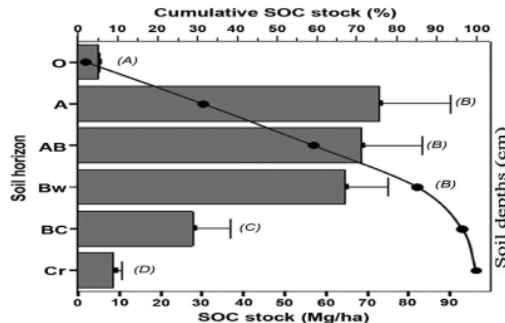

(a)

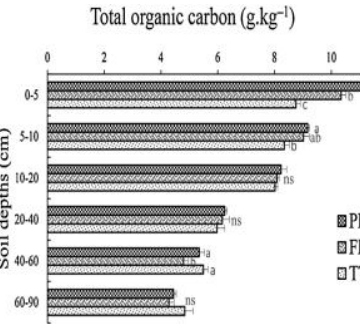

(b)

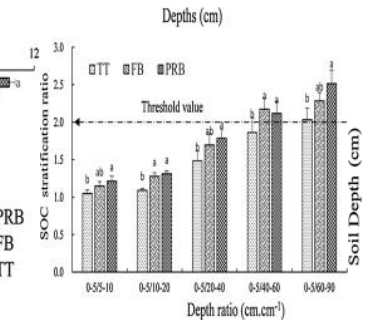

(c)

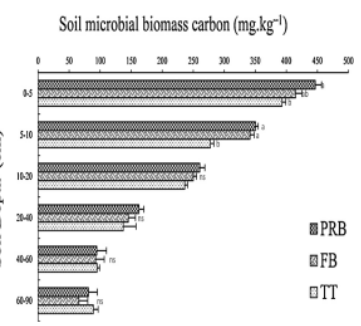

(d)

Fig.3 (a): Cumulative carbon (C) mineralization of bulk soils as affected by 43 years of fertilization in the 0-15 and 15-30 cm soil layer [Source: Ghosh et al., 2016] (b): Effects of straw burial depth on soil organic carbon content in different soil horizons: (a) total organic carbon; (b) labile organic carbon [Source: Wang et al., 2015] (c): Effects of straw burial amount on TOC variation (\%) (a) and LOC variation (\%) (b) in the $10 \mathrm{~cm}$ soil layers above and below straws [Source: Wang et al., 2015]

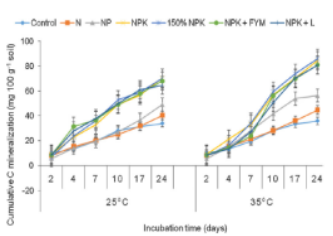

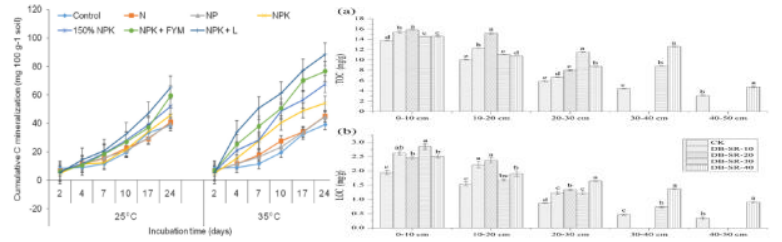

(a) (b)

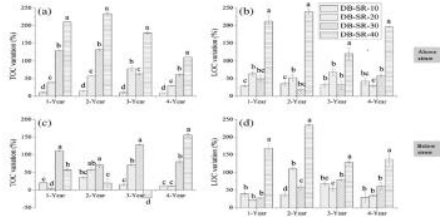

(c) 
Fig.4 (a): Differences of total SOC stocks, as no-tillage (NT) compared to conventional tillage (CT), in different soil depths over different cultivation years [Source: Kuhn et al., 2016] (b): Soil organic carbon stock in relation to aggregate size [Source: Dhaliwal et al., 2018] (c): Simulated changes in the SOC from 2011 to 2050 under different agricultural management scenarios [Source: Yu et al., 2013]

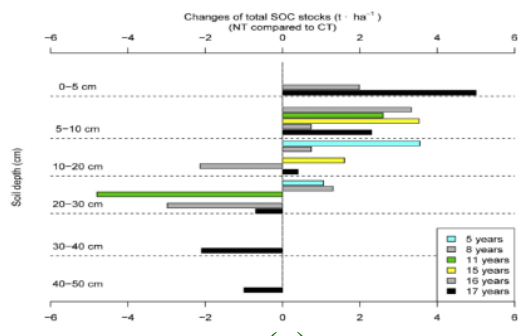

(a)

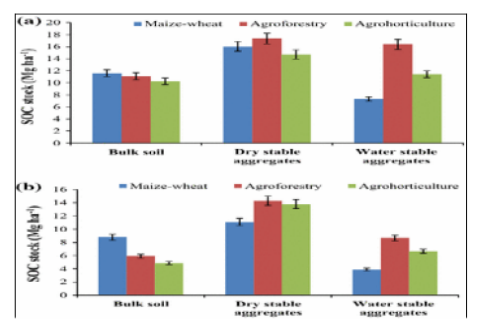

(b)

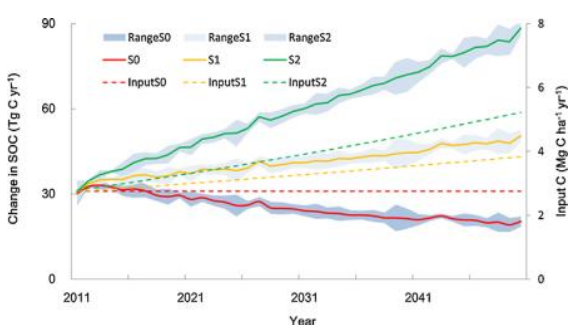

(c)

Fig.5 (a): Soil OC stocks (a) and sequestrations (c) in each restoration stage, and soil OC stocks (b) and sequestrations (d) changes over the time since land-use change [Source: Deng et al., 2016] (b): Carbon concentration in the soil profile [Source: Kätterer et al., 2014] (c): Soil OC decomposition rate constants $(k)$ and rates of new soil $\mathrm{C}$ increase $\left(\mathrm{g} \mathrm{m}^{-2}\right.$ year $\left.{ }^{-1}\right)$ in each restoration stage and changes over time since land-use change [Source: Deng et al., 2016]

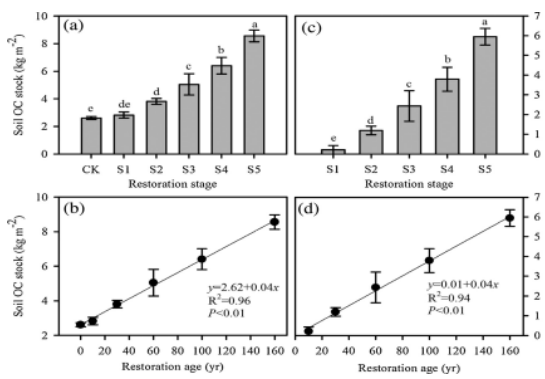

(a)

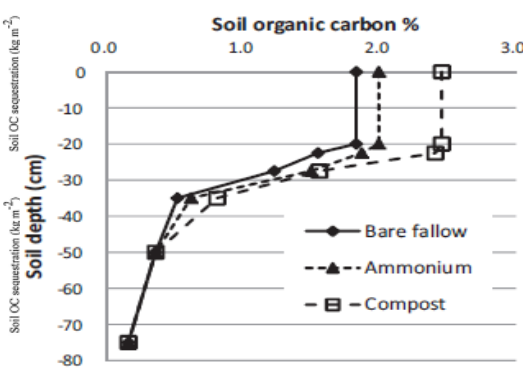

(b)

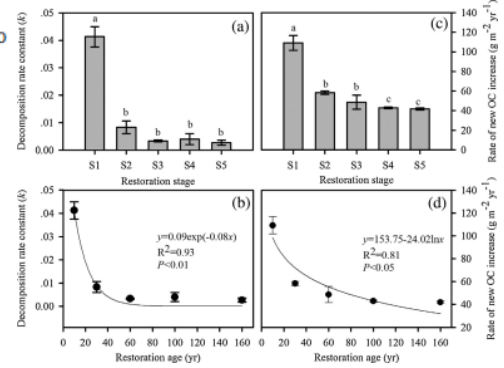

(c)

Fig.6 (a): Bulk soil organic (a) and labile organic carbon (b) concentration ( $\mathrm{g} \mathrm{kg}^{-1}$ soil) in the 0$15 \mathrm{~cm}, 15-30 \mathrm{~cm}, 30-45 \mathrm{~cm}$ and cumulative of 0-45 cm layers expressed as a-b for four land uses (barren land, cultivated land, grass land and forest land) [Source: Meena et al., 2016] (b): Soil carbon sequestration and (b) soil nitrogen sequestration concentration $\left(\mathrm{Mg} \mathrm{ha}^{-1}\right)$ in the $0-15$ $\mathrm{cm}, 15-30 \mathrm{~cm}, 30-45 \mathrm{~cm}$ and cumulative of 0-45 cm layers [Source: Brady and Weil, 2002] (c): soil total carbon (TC), (b) soil total nitrogen (TN) concentration ( $\mathrm{g} \mathrm{kg}^{-1}$ soil) and (c) ratios of soil total carbon and soil total nitrogen $(\mathrm{TC} / \mathrm{TN})$ in the $0-15 \mathrm{~cm}, 15-30 \mathrm{~cm}, 30-45 \mathrm{~cm}$ and cumulative of 0-45 cm layers [Source: Ghosh et al., 2016]

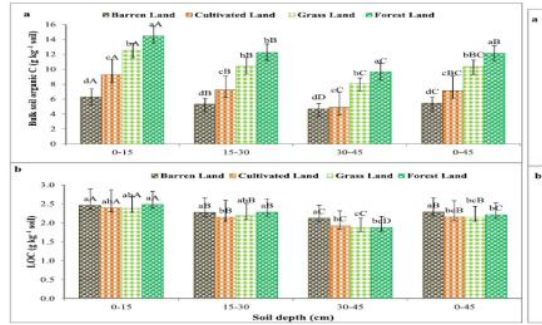

(a)

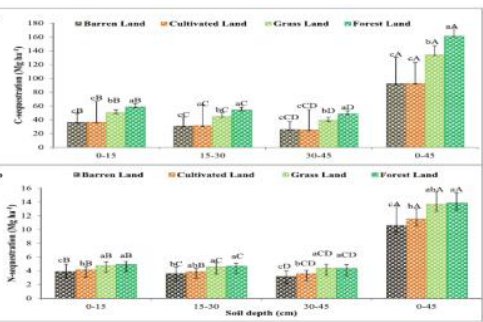

(b)

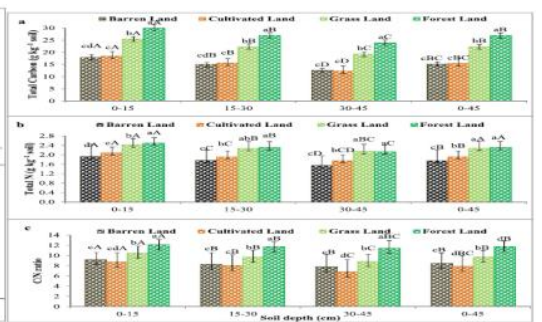

(c) 
Fig.7 (a): Soil organic carbon (SOC) stocks in the residue removed (RR) and residue incorporated (RI) treatments under five different $\mathrm{N}$ fertiliser rates [Source: Poeplau et al., 2017] (b): Soil organic carbon (SOC) stock in different fractions for residues removed (RR) and residues incorporated $(\mathrm{RI})$ treatments at different nitrogen $(\mathrm{N})$ fertilisation rates [Source: Naresh et al., 2018] (c): Effect of cropping system and treatment on occluded POM-C (OPOM-C) dynamics during 330 day incubation [Source: Chen et al., 2014]

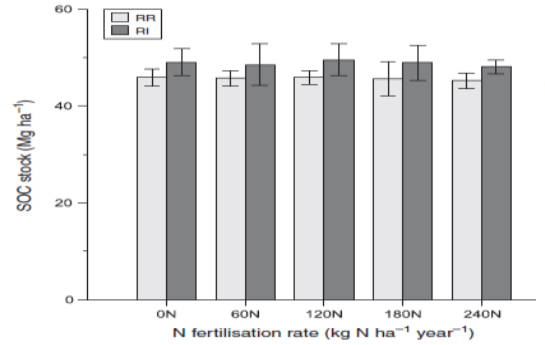

(a)

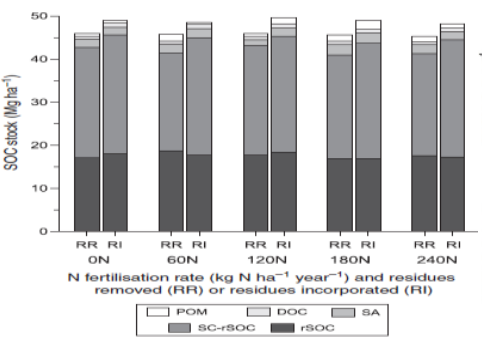

(b)

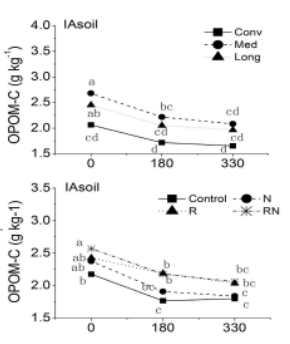

(c)

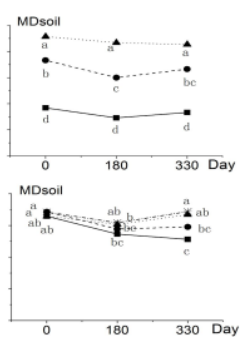

Fig.8 (a): Total organic $\mathrm{C}(\mathrm{a})$, total $\mathrm{N}(\mathrm{b}), \mathrm{C} / \mathrm{N}$ ratio (c), labile $\mathrm{C}$ (d), recalcitrant $\mathrm{C}$ (e) and bulk density (f) in different soil management systems and for different layers [Source: Thomazini et al., 2015] (b): Vertical distribution of bulk density (a), SOC concentration (b) and C: N ratio (c) in the horizons of soil profiles [Source: Soto-Pinto et al., 2010] (c): Land use impact on soil organic matter and carbon contents in plants [Source: Zhang et al., 2018]

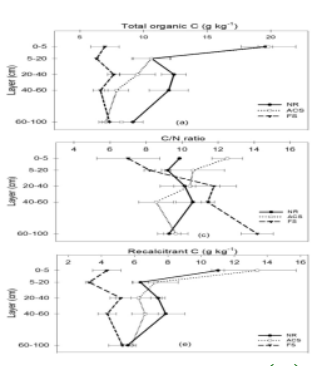

(a)

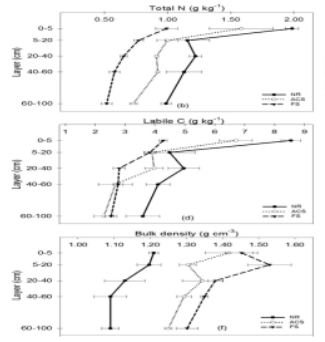

$$
\text { (a) }
$$

Fig.9 (a): Physical and chemical stabilization of soil organic carbon [Source: Cui et al., 2014] (b):Tillage and crop residue management effects on the stock and stabilization of topsoil carbon [Source: Singh et al., 2015] (c): Dynamic changes of residual quantities of OMs in decomposition process under different treatments [Source: Juan et al., 2018] (d): Dynamic changes of quantities of carbon released from OMs in decomposition process under different treatments [Source: Juan et al., 2018]

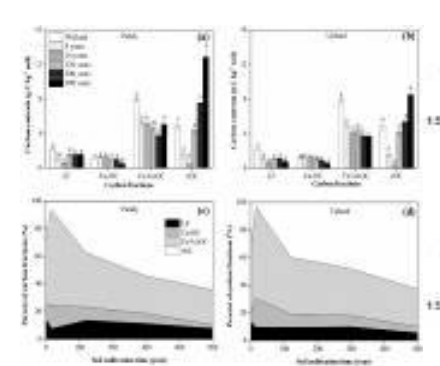

(a)

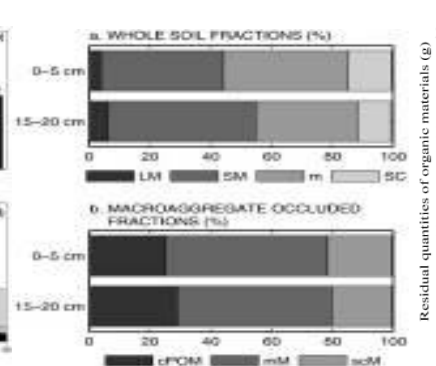

(b)

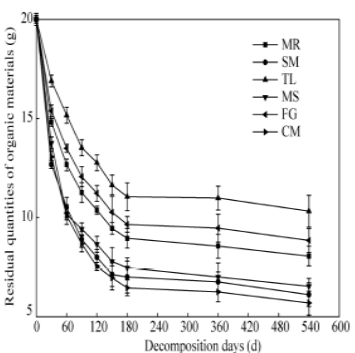

(c)

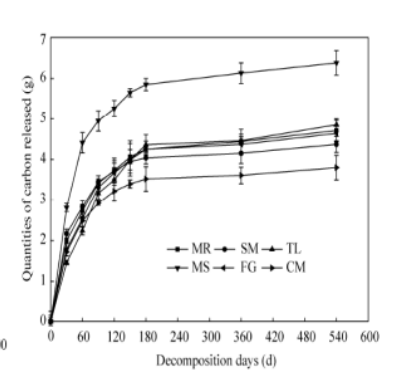

(d) 
Fig.10 (a): POC stocks and those of its components (cPOC, fPOC) in relation to depth and land use systems. LOC, LFOC, ROC, DOC and MBC represent labile organic C, light fraction organic $\mathrm{C}$, readily oxidizable organic $\mathrm{C}$, dissolved organic $\mathrm{C}$, and microbial biomass [Source: Sheng et al., 2015] (b): LOC fraction stocks in relation to depth and land use systems [Source: Mobley et al., 2015] (c): Soil organic C (SOC), dissolved organic C (DOC), microbial biomass C $(\mathrm{MBC}), \mathrm{MBC} / \mathrm{SOC}$, soil $\mathrm{C}: \mathrm{N}$ and microbial $\mathrm{C}: \mathrm{N}$ under different land uses and topographic positions [Source: Zhu et al., 2014]

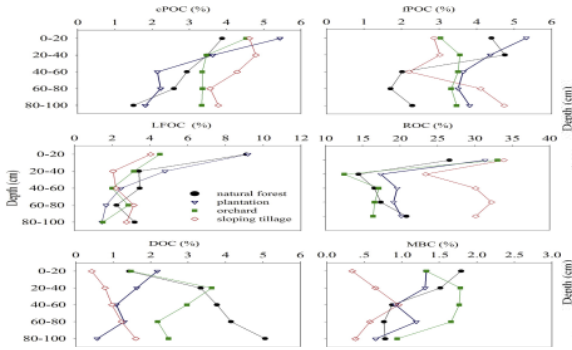

(a)

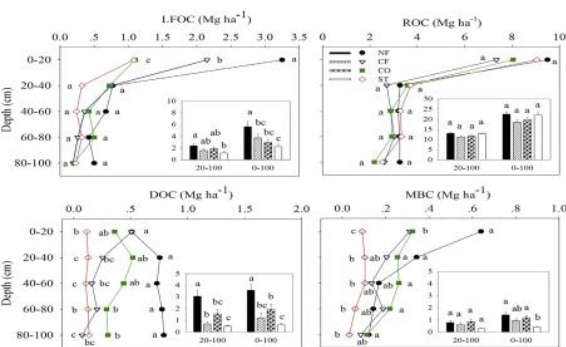

(b)

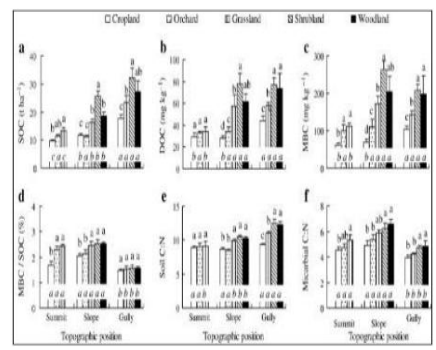

(c)

Fig.11 (a): Distribution of soil organic carbon (SOC, A), total nitrogen (TN, B), particulate organic carbon (POC, C), and labile organic carbon (LOC, D) contents of different land used types in soil depth of 0-200 cm [Source: Zhao et al., 2014]. (b): Total organic carbon (SOC) (a), coarse particulate organic carbon (POCc) (b), fine particulate organic carbon (POCf) (c) and mineral-associated organic carbon (MOC) (d) as affected by cover crops at 0-20 cm depth [Source: Duval et al., 2016]. (c): SOC levels and annual change in SOC in wheat-growing land from 1960 to 2010 [Source: Wang et al., 2015]

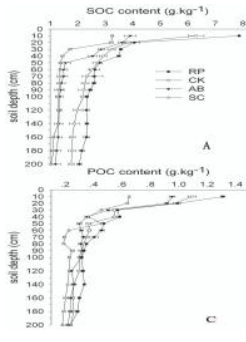

(a)

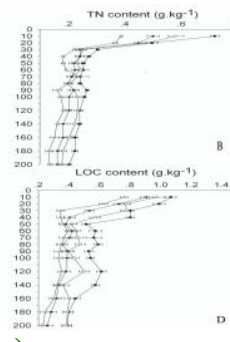

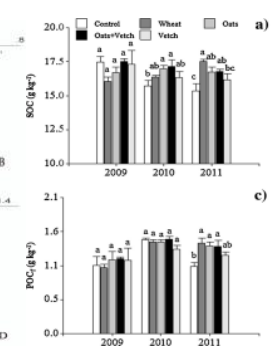

(b)

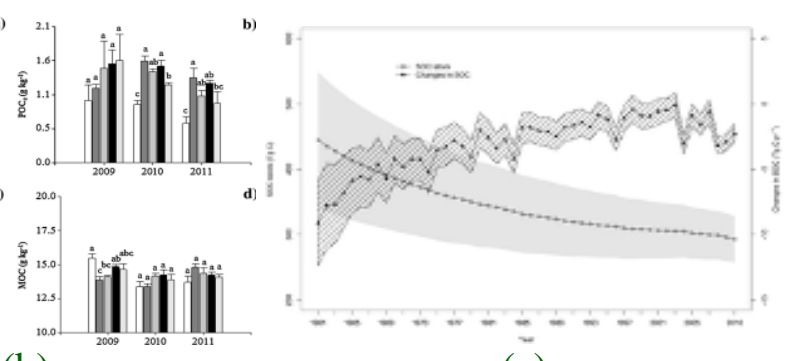

(c)

Fig.12 (a): Soil organic carbon content in the profiles among the different land-use changes [Source: Lihua Zhang et al., 2014] (b): Particulate organic carbon (POC) and POC: SOC ratio in the profiles among the different land-use changes [Source: Su 2007] (c): Labile organic carbon (LOC) and LOC: SOC ratio in the profiles among the different land-use changes [Source: Poeplau and Don (2013Poeplau and Don 2013]

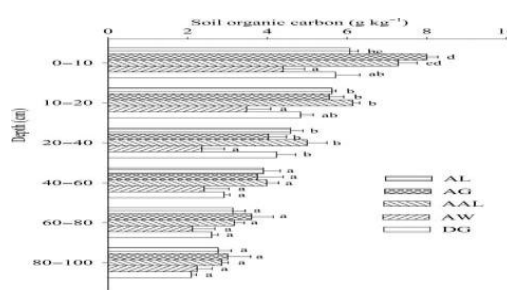

(a)

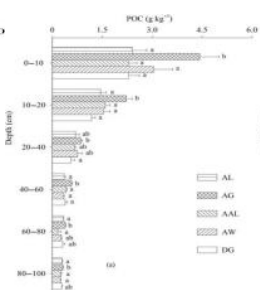

(b)

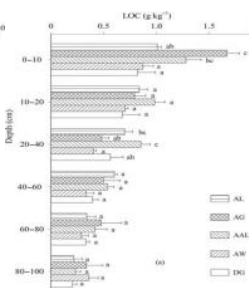

(c) 
Fig.13 (a): Mean weight diameters (A) and geometric mean diameters (B) of soil from two depths among aggregate-size fractions under conventional tillage with residue removal (CT), shallow tillage with residue cover (ST), and no-tillage with residue cover (NT) [Source: Chen et al., 2009] (b): Aggregate-size distribution as determined by wet sieving for (a) the 0-15-cm and (b) the 15-30-cm layers under conventional tillage with residue removal (CT), shallow tillage with residue cover (ST), and no-tillage with residue cover (NT) [Source: Chen et al., 2009] (c): Soil organic carbon (SOC) and nitrogen content $(\mathrm{g} \mathrm{kg} 1)$ of sand-free aggregates from two depths under conventional tillage with residue removal (CT), shallow tillage with residue cover (ST), and no-tillage with residue cover (NT) [Source: Naresh et al., 2018]

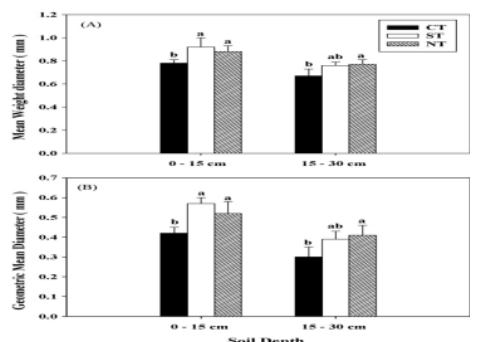

(a)

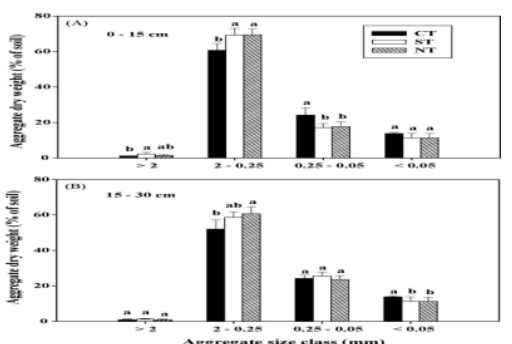

(b)
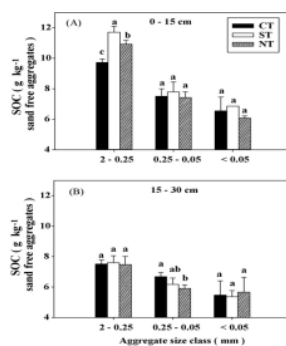

(c)
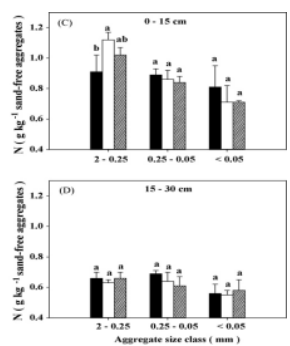

Fig.14 (a): The influence of various farming practices on soil organic carbon (b): Effect of longterm fertilizer applications on depth distribution of bulk density (A), soil organic C (B) and soil organic C storage (C) [Source: Liu et al., 2013] (c): Effect of long-term fertilizer applications on depth distribution of particulate organic $\mathrm{C}(\mathrm{A})$, dissolved organic $\mathrm{C}$ (B) and microbial biomass $\mathrm{C}$ (C) [Source: Liu et al., 2013]

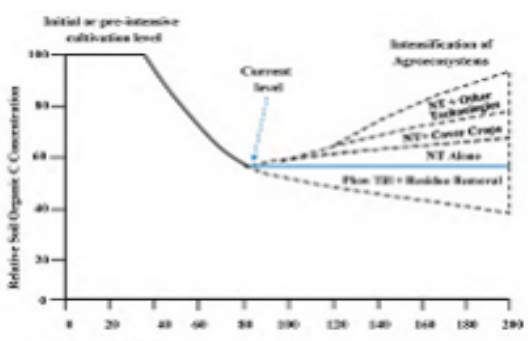

(a)

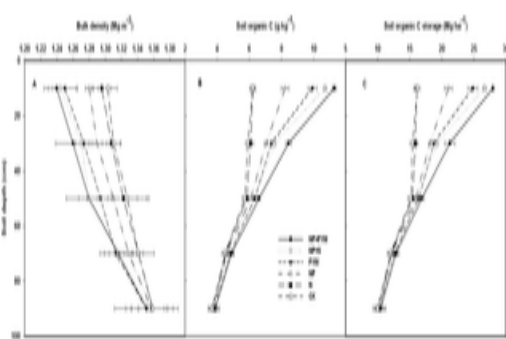

(b)

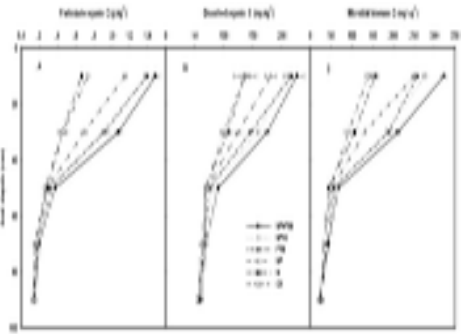

(c)

Fig.15 (a): Effects of conservation tillage, crop residue and cropping systems on changes in soil organic matter [Source: Anyanzwa et al., 2010] (b): Dynamic changes of carbon fractions [Source: Gu et al., 2016] (c): Carbon saturation and assessment of soil organic carbon fractions [Source: Vicente et al., 2017]

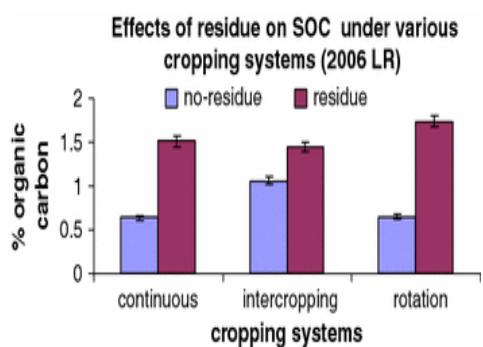

(a)

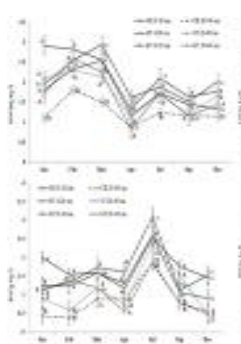

(b)

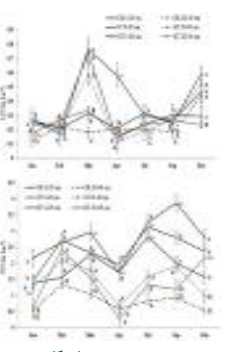

(b)

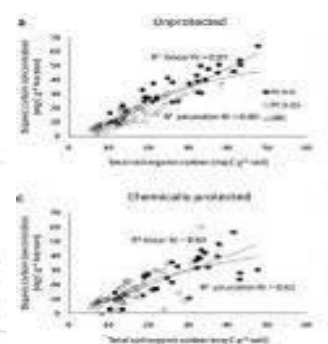

(c)

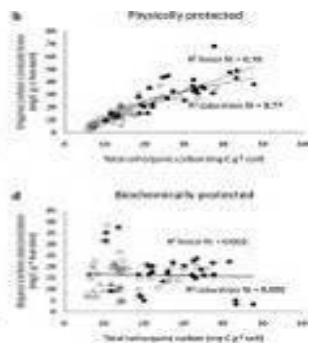


Table.1 Effect of 15 years of application of treatments on contents of various labile fractions of carbon in soil [Naresh et al., 2017]

\begin{tabular}{|c|c|c|c|c|c|c|c|c|c|c|}
\hline \multirow[b]{2}{*}{ Treatments } & \multicolumn{5}{|c|}{$0-5 \mathrm{~cm}$ layer } & \multicolumn{5}{|c|}{$5-15 \mathrm{~cm}$ layer } \\
\hline & $\begin{array}{c}\text { WSC } \\
\left(\mathrm{mgkg}^{-1}\right)\end{array}$ & $\begin{array}{c}\text { POC } \\
\left(\mathrm{mgkg}^{-1}\right)\end{array}$ & $\begin{array}{c}\text { PON } \\
\left(\mathrm{mgkg}^{-1}\right)\end{array}$ & $\begin{array}{c}\text { LFOC } \\
\left(\mathrm{mgkg}^{-1}\right)\end{array}$ & $\begin{array}{c}\text { LFON } \\
\left(\mathrm{mgkg}^{-1}\right)\end{array}$ & $\begin{array}{c}\text { WSC } \\
\left(\mathrm{mgkg}^{-1}\right)\end{array}$ & $\begin{array}{c}\mathrm{POC} \\
\left(\mathrm{mgkg}^{-1}\right)\end{array}$ & $\begin{array}{c}\text { PON } \\
\left(\mathrm{mgkg}^{-1}\right)\end{array}$ & $\begin{array}{c}\text { LFOC } \\
\left(\mathrm{mgkg}^{-1}\right)\end{array}$ & $\begin{array}{c}\text { LFON } \\
\left(\mathrm{mgkg}^{-1}\right)\end{array}$ \\
\hline \multicolumn{11}{|c|}{ Tillage crop residue practices } \\
\hline $\mathrm{T}_{1}$ & $23.9^{\mathrm{d}}$ & $638^{\mathrm{d}}$ & $67.2^{\mathrm{d}}$ & $81.3^{\mathrm{d}}$ & $9.1^{\mathrm{d}}$ & $15.7^{\mathrm{d}}$ & $535^{\mathrm{e}}$ & $54.7^{\mathrm{e}}$ & $65.1^{\mathrm{d}}$ & $7.8^{\mathrm{d}}$ \\
\hline $\mathrm{T}_{2}$ & $25.9^{c}$ & $898^{\text {bc }}$ & $88.6^{\mathrm{cd}}$ & $107.8^{\mathrm{bc}}$ & $11.8^{\mathrm{c}}$ & $17.8^{\mathrm{cd}}$ & $674^{\mathrm{cd}}$ & $74.5^{\mathrm{cd}}$ & $94.1^{\mathrm{bc}}$ & $9.1^{\mathrm{c}}$ \\
\hline $\mathrm{T}_{3}$ & $27.8^{\mathrm{ab}}$ & $1105^{\mathrm{ab}}$ & $106.7^{\mathrm{ab}}$ & $155.2^{\mathrm{a}}$ & $13.3^{\mathrm{ab}}$ & $19.6^{\mathrm{bc}}$ & $785^{\mathrm{bc}}$ & $91.8^{\mathrm{ab}}$ & $132.6^{\mathrm{a}}$ & $10.9^{\mathrm{ab}}$ \\
\hline $\mathrm{T}_{4}$ & $22.7^{\mathrm{d}}$ & $779^{\mathrm{cd}}$ & $77.9^{\mathrm{d}}$ & $95.7^{\mathrm{c}}$ & $9.8^{\mathrm{d}}$ & $17.6^{\mathrm{cd}}$ & $609^{\text {de }}$ & $69.1^{\text {de }}$ & $87.6^{c}$ & $8.3^{\mathrm{cd}}$ \\
\hline$T_{5}$ & $26.4^{\mathrm{bc}}$ & $1033^{\mathrm{b}}$ & $97.4^{\mathrm{bc}}$ & $128.8^{\mathrm{b}}$ & $12.6^{\mathrm{bc}}$ & $20.3^{\mathrm{ab}}$ & $842^{\mathrm{ab}}$ & $87.3^{\text {bc }}$ & $102.9^{\mathrm{b}}$ & $10.4^{\mathrm{b}}$ \\
\hline $\mathrm{T}_{6}$ & $29.2^{\mathrm{a}}$ & $1357^{\mathrm{a}}$ & $117.5^{\mathrm{a}}$ & $177.8^{\mathrm{a}}$ & $14.2^{\mathrm{a}}$ & $22.6^{a}$ & $974^{\mathrm{a}}$ & $106.1^{\mathrm{a}}$ & $141.2^{\mathrm{a}}$ & $11.8^{\mathrm{a}}$ \\
\hline $\mathrm{T}_{7}$ & $17.2^{\mathrm{e}}$ & $620^{\mathrm{d}}$ & $22.5^{\mathrm{e}}$ & $52.7^{\mathrm{e}}$ & $8.2^{\mathrm{d}}$ & $13.2^{\mathrm{e}}$ & $485^{\mathrm{e}}$ & $18.8^{f}$ & $49.8^{\mathrm{e}}$ & $6.8^{\mathrm{e}}$ \\
\hline \multicolumn{11}{|c|}{ Nutrient Management Practices } \\
\hline$F_{1}$ & $21.9^{\mathrm{e}}$ & $631^{\mathrm{d}}$ & $24.7^{\mathrm{e}}$ & $89.2^{c}$ & $6.8^{\mathrm{d}}$ & $15.1^{\mathrm{e}}$ & 585 & $17.3^{\mathrm{e}}$ & $47.9^{f}$ & $5.9^{\mathrm{e}}$ \\
\hline $\mathrm{F}_{2}$ & $29.2^{\mathrm{cd}}$ & $869^{c}$ & $92.5^{\mathrm{c}}$ & $96.4^{\mathrm{c}}$ & $9.5^{c}$ & $20.2^{\mathrm{cd}}$ & 789 & $73.5^{\mathrm{cd}}$ & $85.9^{\mathrm{d}}$ & $8.9^{c}$ \\
\hline F3 & $29.8^{c}$ & $956^{\mathrm{bc}}$ & $96.8^{c}$ & $108.1^{\mathrm{bc}}$ & $10.5^{\mathrm{bc}}$ & $21.9^{\mathrm{bc}}$ & 813 & $79.4^{c}$ & $96.9^{\mathrm{cd}}$ & $9.6^{\mathrm{bc}}$ \\
\hline $\mathrm{F}_{4}$ & $28.4^{\mathrm{d}}$ & $788^{\mathrm{cd}}$ & $72.9^{d}$ & $91.3^{c}$ & $7.9^{\mathrm{d}}$ & $18.8^{\mathrm{d}}$ & 728 & $59.4^{d}$ & $66.7^{e}$ & $7.2^{\mathrm{d}}$ \\
\hline $\mathrm{F}_{5}$ & $32.5^{\mathrm{a}}$ & $1381^{\mathrm{a}}$ & $130.8^{\mathrm{a}}$ & $183.9^{\mathrm{a}}$ & $13.8^{\mathrm{a}}$ & $26.4^{\mathrm{a}}$ & $1032 \mathrm{a}$ & $112.1^{\mathrm{a}}$ & $152.9^{\mathrm{a}}$ & $12.4^{\mathrm{a}}$ \\
\hline F6 & $31.6^{\mathrm{ab}}$ & $1156^{\mathrm{ab}}$ & $114.2^{\mathrm{ab}}$ & $160.5^{\mathrm{a}}$ & $12.6^{\mathrm{ab}}$ & $23.6^{\mathrm{ab}}$ & $905 \mathrm{ab}$ & $96.7^{\mathrm{ab}}$ & $139.7^{\mathrm{a}}$ & $11.9^{\mathrm{a}}$ \\
\hline$F_{7}$ & $30.9^{b}$ & $1102^{b}$ & $103.9^{\mathrm{bc}}$ & $123.5^{\mathrm{b}}$ & $11.5^{b}$ & $22.7^{b}$ & $826 b$ & $88.3^{\text {bc }}$ & $103.2^{\mathrm{bc}}$ & $10.1^{\mathrm{b}}$ \\
\hline
\end{tabular}

Values in a column followed by the same letter are not significantly different $(\mathrm{P}<0.05)$.

WSC $=$ water soluble $\mathrm{C}, \mathrm{POC}=$ particulate organic $\mathrm{C}, \mathrm{PON}=$ particulate organic $\mathrm{N}, \mathrm{LFOC}=$ light fraction organic $\mathrm{C}$, and $\mathrm{LFON}=$ light fraction organic $\mathrm{N}$.

Table.2 Oxidisable organic carbon fractions (very labile, labile, less labile and non-labile) in soils $\left(\mathrm{g} \mathrm{kg}^{-1}\right)$ at different layers (cm) [Krishna et al., 2018]

\begin{tabular}{|c|c|c|c|c|c|c|c|c|}
\hline \multirow{2}{*}{ Treatment } & \multicolumn{4}{|c|}{ Very labile C } & \multicolumn{4}{|c|}{ Labile C } \\
\hline & $0-15$ & $15-30$ & $30-45$ & Total & $0-15$ & $15-30$ & $30-45$ & Total \\
\hline Control & $3.6 \pm 0.5^{c}$ & $1.4 \pm 0.3^{b}$ & $1.3 \pm 0.2^{\mathrm{a}}$ & $6.3 \pm 0.4^{b}$ & $2.4 \pm 0.3^{\mathrm{n}}$ & 1. $0 \pm 0.2^{a}$ & $0.8 \pm 0.4^{\mathrm{a}}$ & $4.2 \pm 0.6^{\mathrm{a}}$ \\
\hline $50 \%$ NPK & $4.6 \pm 0.3^{\mathrm{bc}}$ & $2.1 \pm 0.7^{\mathrm{ab}}$ & $1.5 \pm 0.1^{\mathrm{a}}$ & $8.1 \pm 0.9^{\mathrm{a}}$ & $1.7 \pm 0.4^{\mathrm{ab}}$ & $0.9 \pm 0.5^{a}$ & $0.7 \pm 0.2^{\mathrm{a}}$ & $3.3 \pm 0.7^{a}$ \\
\hline $100 \%$ NPK & $4.4 \pm 0.3^{\mathrm{bc}}$ & $2.3 \pm 0.2^{a}$ & $1.4 \pm 0.5^{\mathrm{a}}$ & $8.0 \pm 0.7^{\mathrm{a}}$ & $1.8 \pm 0.4^{\text {ab }}$ & $0.8 \pm 0.5^{a}$ & $0.6 \pm 0.3^{\mathrm{a}}$ & $3.2 \pm 0.8^{\mathrm{a}}$ \\
\hline $150 \%$ NPK & $5.0 \pm 0.2^{\mathrm{ab}}$ & $2.6 \pm 0.2^{\mathrm{a}}$ & $1.5 \pm 0.1^{\mathrm{a}}$ & $9.0 \pm 0.3^{\mathrm{a}}$ & $1.2 \pm 0.3^{b}$ & $0.7 \pm 0.2^{\mathrm{a}}$ & $0.9 \pm 0.2^{\mathrm{a}}$ & $2.8 \pm 0.4^{\mathrm{a}}$ \\
\hline $100 \%$ NPK +FYM & $4.8 \pm 0.2^{\mathrm{ab}}$ & $2.0 \pm 0.2^{\mathrm{ab}}$ & $1.3 \pm 0.3^{\mathrm{a}}$ & $8.1 \pm 0.2^{a}$ & $1.9 \pm 0.3^{\mathrm{ab}}$ & $0.7 \pm 0.2^{\mathrm{a}}$ & $0.7 \pm 0.3^{a}$ & $3.4 \pm 0.2^{\mathrm{a}}$ \\
\hline FYM & $5.9 \pm 1.3^{\mathrm{a}}$ & $2.2 \pm 0.2^{a}$ & $1.4 \pm 0.3^{\mathrm{a}}$ & $9.5 \pm 1.6^{\mathrm{a}}$ & $2.5 \pm 0.9^{\mathrm{a}}$ & $0.7 \pm 0.3^{\mathrm{a}}$ & $0.7 \pm 0.2^{\mathrm{a}}$ & $3.9 \pm 0.9^{\mathrm{a}}$ \\
\hline \multirow[t]{2}{*}{ Fallow } & $4.2 \pm 0.7^{\text {be }}$ & $1.5 \pm 0.5^{b}$ & $0.7 \pm 0.3^{b}$ & $6.3 \pm 0.8^{b}$ & $2.2 \pm 1.0^{\mathrm{ab}}$ & $1.0 \pm 0.3^{\mathrm{a}}$ & $1.0 \pm 0.4^{\mathrm{a}}$ & $4.1 \pm 1.1^{\mathrm{A}}$ \\
\hline & \multirow{2}{*}{\multicolumn{4}{|c|}{ Less labile C }} & \multicolumn{4}{|c|}{ Non labile $\mathrm{C}$} \\
\hline Control & $1.5 \pm 0.3^{\mathrm{c}}$ & & & $2.6 \pm 0.7^{\mathrm{d}}$ & $1.2 \pm 0.5^{b}$ & $1.2 \pm 0.3^{a}$ & $0.2 \pm 0.2^{\mathrm{b}}$ & $2.6 \pm 0.5^{b}$ \\
\hline $50 \%$ NPK & $1.8 \pm 0.1^{\mathrm{C}}$ & $0.4 \pm 0.1^{\mathrm{C}}$ & $0.5 \pm 0.2^{\mathrm{c}}$ & $2.7 \pm 0.1^{\mathrm{ed}}$ & $1.2 \pm 0.9^{b}$ & $1.7 \pm 0.8^{a}$ & $0.7 \pm 0.4^{\mathrm{ab}}$ & $3.5 \pm 1.8^{\mathrm{ab}}$ \\
\hline $100 \%$ NPK & $2.5 \pm 0.3^{\text {ab }}$ & $0.8 \pm 0.1^{\mathrm{bc}}$ & $1.1 \pm 0.2^{\mathrm{ab}}$ & $4.4 \pm 0.1^{b}$ & $1.3 \pm 0.6^{b}$ & $1.5 \pm 0.6^{\mathrm{a}}$ & $0.5 \pm 0.2^{\mathrm{ab}}$ & $3.3 \pm 1.0^{\mathrm{abb}}$ \\
\hline $150 \%$ NPK & $2.6 \pm 0.2^{\mathrm{a}}$ & $0.9 \pm 0.1^{\mathrm{bc}}$ & $0.4 \pm 0.2^{\mathrm{c}}$ & $3.9 \pm 0.1^{\mathrm{b}}$ & $1.4 \pm 0.3^{b}$ & $1.5 \pm 0.2^{\mathrm{a}}$ & $0.8 \pm 0.1^{\mathrm{a}}$ & $3.7 \pm 0.3^{\mathrm{ab}}$ \\
\hline $100 \%$ NPK +FYM & $2.7 \pm 0.6^{\mathrm{a}}$ & $1.5 \pm 0.2^{\mathrm{a}}$ & $1.4 \pm 0.1^{\mathrm{a}}$ & $5.6 \pm 0.7^{a}$ & $2.0 \pm 0.8^{b}$ & $1.3 \pm 0.1^{\mathrm{a}}$ & $0.3 \pm 0.3^{\text {ab }}$ & $3.5 \pm 0.7^{\mathrm{ab}}$ \\
\hline FYM & $1.9 \pm 0.7^{\mathrm{bc}}$ & $1.7 \pm 0.2^{\mathrm{a}}$ & $1.0 \pm 0.2^{b}$ & $4.5 \pm 0.7^{\mathrm{ab}}$ & $3.7 \pm 1.3^{a}$ & $1.0 \pm 0.2^{\mathrm{a}}$ & $0.5 \pm 0.5^{\text {ab }}$ & $5.1 \pm 1.9^{\mathrm{a}}$ \\
\hline Fallow & $1.5 \pm 0.3^{\mathrm{e}}$ & $1.3 \pm 0.7^{\mathrm{ab}}$ & $0.9 \pm 0.4^{b}$ & $3.8 \pm 1.2^{\mathrm{be}}$ & $2.1 \pm 0.2^{b}$ & $1.4 \pm 0.7^{\mathrm{a}}$ & $0.4 \pm 0.2^{\mathrm{ab}}$ & $3.9 \pm 0.9^{\mathrm{ab}}$ \\
\hline
\end{tabular}

"values in the same column followed by different letters are significantly different at $\mathrm{P}<0.001$ according to Duncan's Multiple

Range Test (DMRT) for separation of means, \pm indicates the standard deviation values.

Table.3 Soil organic carbon (SOC) pools under different management regimes in surface soil (0$10 \mathrm{~cm})$ and subsurface $(10-30 \mathrm{~cm})$ paddy growing soils [Nath et al., 2015]

\begin{tabular}{|c|c|c|c|c|c|c|c|}
\hline \multirow[b]{2}{*}{ Treatments } & \multicolumn{5}{|c|}{ Sub fractionation of organic carbon (\%) } & \multirow[b]{2}{*}{$\begin{array}{c}\text { Active pool } \\
\left(C_{A P}\right)\end{array}$} & \multirow[b]{2}{*}{$\begin{array}{c}\text { Passive pool } \\
\left(C_{\mathrm{PP}}\right)\end{array}$} \\
\hline & $\begin{array}{c}\text { Very labile } \\
\left(\mathrm{C}_{\mathrm{VL}}\right)\end{array}$ & $\begin{array}{c}\text { Labile } \\
\left(\mathrm{C}_{\mathrm{L}}\right)\end{array}$ & $\begin{array}{c}\text { Less labile } \\
\left(\mathrm{C}_{\text {LL }}\right)\end{array}$ & $\begin{array}{c}\text { Non-labile } \\
\left(\mathrm{C}_{\mathrm{NL}}\right)\end{array}$ & TOC $(\%)$ & & \\
\hline \multicolumn{8}{|c|}{$0-10 \mathrm{~cm}$} \\
\hline Control & $0.28(22 \%)$ & $0.04(3 \%)$ & $0.10(8 \%)$ & $0.88(67 \%)$ & $1.30^{\mathrm{a}}$ & $25 \%$ & $75 \%$ \\
\hline VM & $0.33(24 \%)$ & $0.10(7 \%)$ & $0.17(12 \%)$ & $0.76(57 \%)$ & $1.36^{\mathrm{b}}$ & $31 \%$ & $69 \%$ \\
\hline Inorganic & $0.30(23 \%)$ & $0.10(8 \%)$ & $0.14(11 \%)$ & $0.79(59 \%)$ & $1.33^{\mathrm{a}}$ & $30 \%$ & $70 \%$ \\
\hline Organic & $0.36(25 \%)$ & $0.13(9 \%)$ & $0.12(8 \%)$ & $0.85(59 \%)$ & $1.46^{\mathrm{ab}}$ & $34 \%$ & $66 \%$ \\
\hline Organic+Inorganic & $0.37(26 \%)$ & $0.14(10 \%)$ & $0.05(4 \%)$ & $0.87(60 \%)$ & $1.43^{\mathrm{ab}}$ & $36 \%$ & $64 \%$ \\
\hline \multicolumn{8}{|c|}{$10-30 \mathrm{~cm}$} \\
\hline Control & $0.13(19 \%)$ & $0.06(9 \%)$ & $0.16(23 \%)$ & $0.35(50 \%)$ & $0.70^{\mathrm{a}}$ & $27 \%$ & $73 \%$ \\
\hline VM & $0.15(19 \%)$ & $0.10(13 \%)$ & $0.15(20 \%)$ & $0.40(49 \%)$ & $0.80^{\mathrm{b}}$ & $31 \%$ & $69 \%$ \\
\hline Inorganic & $0.13(16 \%)$ & $0.11(14 \%)$ & $0.17(21 \%)$ & $0.40(49 \%)$ & $0.81^{\mathrm{b}}$ & $30 \%$ & $70 \%$ \\
\hline Organic & $0.14(19 \%)$ & $0.09(12 \%)$ & $0.10(14 \%)$ & $0.41(55 \%)$ & $0.74^{\mathrm{ab}}$ & $31 \%$ & $69 \%$ \\
\hline Organic+Inorganic & $0.16(19 \%)$ & $0.09(11 \%)$ & $0.15(18 \%)$ & $0.45(53 \%)$ & $0.85^{\circ}$ & $29 \%$ & $71 \%$ \\
\hline \multicolumn{8}{|c|}{$0-30 \mathrm{~cm}$} \\
\hline Control & $0.21(21 \%)$ & $0.05(5 \%)$ & $0.13(13 \%)$ & $0.61(61 \%)$ & 1. $\mathrm{O}^{\mathrm{a}}$ & $26 \%$ & $74 \%$ \\
\hline VM & $0.24(22 \%)$ & $0.10(9 \%)$ & $0.16(15 \%)$ & $0.58(54 \%)$ & $1.08^{b}$ & $31 \%$ & $69 \%$ \\
\hline Inorganic & $0.22(20 \%)$ & $0.11(10 \%)$ & $0.16(14 \%)$ & $0.60(56 \%)$ & $1.07^{\mathrm{b}}$ & $30 \%$ & $70 \%$ \\
\hline Organic & $0.25(23 \%)$ & $0.11(10 \%)$ & $0.11(10 \%)$ & $0.63(57 \%)$ & $1.24^{\mathrm{ab}}$ & $33 \%$ & $67 \%$ \\
\hline Organic+Inorganic & $0.27(23 \%)$ & $0.12(10 \%)$ & $0.10(9 \%)$ & $0.66(58 \%)$ & $1.14^{\mathrm{ab}}$ & $33 \%$ & $67 \%$ \\
\hline
\end{tabular}


Simulations indicated that approximately $80 \%$ of the loss of SOC across wheat-growing areas occurred in the first 30 years, with a lower amount of SOC loss in the later 20 years. SOC loss appeared to reach a new steady-state during the first few years of the 2000. The achievement of steady-state SOC level is attributed to two primary factors. First, enhanced crop production increased the amount of residue and root input into the soil, thus leading to a reduction in SOC loss over time. Second, following the initial rapid decline, SOC would reach a new steady-state after about 50 years of cultivation, therefore resulting in a slower rate of SOC loss during the later years (Lal, 2004a).

Krishna et al., (2018) reported that the total organic carbon (TOC) allocated into different pools in order of very labile > less labile > non labile >labile, constituting about 41.4, 20.6, 19.3 and $18.7 \%$, respectively. In comparison with control, system receiving farmyard manure (FYM-10 Mg ha ${ }^{-1}$ season- ${ }^{1}$ ) alone showed greater $\mathrm{C}$ build up $(40.5 \%)$ followed by 100\% NPK+FYM (120:60:40 kg $\mathrm{N}, \mathrm{P}, \mathrm{K} \mathrm{ha} \mathrm{h}^{-1}+5 \mathrm{Mg}$ FYM ha season $^{-1}$ ) $(16.2 \%)$. In fact, a net depletion of carbon stock was observed with $50 \%$ NPK $(-1.2 \mathrm{Mg}$ $\left.\mathrm{ha}^{-1}\right)$ and control $\left(-1.8 \mathrm{Mg} \mathrm{ha}^{-1}\right)$ treatments. Only $28.9 \%$ of C applied through FYM was stabilized as SOC. A minimal input of 2.34 $\mathrm{Mg} \mathrm{C}$ ha $^{-1} \mathrm{y}^{-1}$ is needed to maintain SOC level [Table 2]. The magnitude of carbon pools extracted under a gradient of oxidizing conditions was as follows: $\mathrm{C}_{\mathrm{VL}}>\mathrm{C}_{\mathrm{LL}}>\mathrm{C}_{\mathrm{NL}}>$ $\mathrm{C}_{\mathrm{L}}$ constituting about 41.4, 20.6, and 19.3 and $18.7 \%$, respectively, of the TOC [Table 2]. However, the contribution of VL, L and LL pools to SOC was 51.2, 23.1 and $25.5 \%$, respectively. While active pool $\left(\mathrm{C}_{\mathrm{VL}}+\mathrm{C}_{\mathrm{L}}\right)$ constituted about $60.1 \%$, passive pool $\left(\mathrm{C}_{\mathrm{LL}}+\right.$ $\mathrm{C}_{\mathrm{NL}}$ ) represented $39.9 \%$ of the TOC.

Among the treatments, $100 \%$ NPK+FYM $(44.4 \%)$ maintained a proportionately higher amount of soil $\mathrm{C}$ in passive pools. With an increase in the dose of fertilization, on average, $\mathrm{C}$ allocation into passive pool was increased $(33.0,35.3,40.7 \%$ and $39.3 \%$ of TOC under control, 50\% NPK, 100\% NPK and $150 \%$ NPK treatments, respectively).

Lihua Zhang et al., (2014) reported that the significant increases $(31.83 \%)$ in the SOC concentrations were observed at AG compared with $\mathrm{AL}$ at a depth of $0-10 \mathrm{~cm}$, with no significant effect at a depth of 10-100 $\mathrm{cm}$ [Fig. 12a]. SOC in the profile showed an increasing trend from $\mathrm{AL}$ to $\mathrm{AAL}$ and from DG to AL, with amplitudes of $20.09 \%$ and $6.23 \%$ at the depth of $0-10 \mathrm{~cm}$. It displayed a decreasing trend of $17.12-44.35 \%$ from DG to $\mathrm{AW}$. The difference in SOC content was significant between the depths of $0-10,10-20$ and $20-100 \mathrm{~cm}$ for each land use type. The influence of land use and soil depth on SOC content was all significant. Consistent with the accumulation of SOC, POC content at the $0-100 \mathrm{~cm}$ depth at AG showed significant enrichment compared with AL [Fig. 12b]. The increase $(92.83 \%)$ was most obvious at the $0-10 \mathrm{~cm}$ depth. The ratio of POC/SOC in the soil profile showed a higher trend at AG relative to AL [Fig. 12b]. LOC in the profile showed an increasing trend after conversion of DG to AL, while POC tended to increase at the $0-40 \mathrm{~cm}$ depth and to decrease at the 40$100 \mathrm{~cm}$ depth [Fig. 12b]. Su (2007) found SOC and POC at the $0-5 \mathrm{~cm}$ depth increased by $35 \%$ and $52.4 \%$ following the same LUC. Li et al., (2009) reported that SOC and POC in the $0-10 \mathrm{~cm}$ layer increased $22 \%$ and $44 \%$, respectively, under perennial grass of 4 years on former cropland. This suggests that accumulated SOC might occur primarily in the POC fraction, and POC and LOC may serve as sensitive indicator for the impact of short-term land use and management practices on SOC. The increment of LOC (23.17$23.67 \%)$ was greater than that of POC (0.17$10.0 \%$ ). POC/SOC showed a decreasing trend 
from DG to $\mathrm{AL}$, with an increasing trend in LOC/ SOC [Fig. 12c]. Poeplau and Don (2013), who found the POC fraction to increase after the conversion of grassland to forest, while the total SOC stock did not change or declined. They identified carbon losses mainly in micro-aggregates, which is attributable to the fine and dense root mat of pasture which promotes the formation of small but very stable aggregates in which carbon is stabilized.

Chen et al., (2009) revealed that the MWD and GMD of soil aggregates were significantly influenced by tillage [Fig. 13a]. At $0-15 \mathrm{~cm}$, MWDs and GMDs were significantly lower under CT than ST or NT, whereas the differences between ST and NT were not significant [Fig. 13a]. At 15-30 cm, ST and NT had higher MWD and GMD than $\mathrm{CT}$, but the differences were only significant between CT and NT [Fig. 13a]. Both MWDs and GMDs decreased with increase in soil depth for all tillage treatments [Fig. 13a]. Chen et al., (2009) stated that the content of large macro-aggregates $(>2 \mathrm{~mm})$ was very low (around $1 \%$ of the soil weight) [Fig. 13b]. Small macro-aggregates $(2-0.25 \mathrm{~mm})$ represented the greatest portions $(52-70 \%$ of whole soil) in all treatments at both $0-15$ and $15-30 \mathrm{~cm}$. At $0-15 \mathrm{~cm}, \mathrm{CT}$ contained significantly less small macro-aggregates (2$0.25 \mathrm{~mm}$ ) than ST or NT, which were not different from each other [Fig. 13b]. In contrast, CT had significantly higher amounts of micro-aggregates $(0.25-0.05 \mathrm{~mm})$ than ST or NT, which were similar [Fig. 13b]. At 15$30 \mathrm{~cm}, \mathrm{ST}$ and NT contained higher amounts of small macro-aggregates than CT; the difference was only significant between CT and NT [Fig. 13b]. However, the $<0.05 \mathrm{~mm}$ fraction was dominated by CT [Fig. 13b].

Naresh et al., (2018) reported that the amount of large macro-aggregates was extremely low and made up of almost all rocks, therefore
SOC and Nt content was not determined in large macro-aggregates. The influence of tillage on aggregate $\mathrm{C}$ and $\mathrm{Nt}$ content is shown in [Fig. 13c]. At $0-15 \mathrm{~cm}$, tillage effect was confined to the $2-0.25 \mathrm{~mm}$ size fraction, in which the conservation tillage treatments contained significantly higher SOC contents than CT, ST had significantly higher $\mathrm{Nt}$ contents than CT, and NT tended to have higher $\mathrm{Nt}$ contents than $\mathrm{CT}$ [Fig. 13c]. No significant differences were detected in SOC and $\mathrm{Nt}$ contents in the $0.25-0.05 \mathrm{~mm}$ and $<0.05 \mathrm{~mm}$ classes among all treatments [Fig. 13c]. The highest SOC and Nt contents were found in the $2-0.25$ size fraction. Data from the $15-$ to $30-\mathrm{cm}$ samples show generally diminished effect of tillage treatments (Fig. $3 \mathrm{~b}$ and $\mathrm{d}$ ). Soil organic $\mathrm{C}$ and $\mathrm{Nt}$ contents in the aggregate-size fractions generally decreased with increase in soil depth for all treatments [Fig. 13c].

Nath et al., (2015) revealed that the TOC content for all the treatments was high in surface soil $(0-10 \mathrm{~cm})$ than in subsurface soil $(10-30 \mathrm{~cm})$. TOC in surface and sub-surface soil was in the order organic > organic + inorganic > VM >inorganic > control and organic > organic +inorganic > inorganic > $\mathrm{VM}>$ control respectively [Table 3]. Build-up of higher amount of TOC in surface soil over sub-surface soil is attributed to accumulation of organic matter from root biomass and left over crop residues in the former that decreased with soil depth. Addition of root biomass and root exudates results in such variation in soil depths (Kaur et al., 2008). Application of organic manure alone or in combination with inorganic fertilizer considerably increased TOC in $0-10 \mathrm{~cm}$ soil depth than control plot [Table 3].

Liu et al., (2013) reported that long-term application of manure and fertilizer significantly affected soil bulk density (BD) to a depth of $40 \mathrm{~cm}$ [Fig. 14b]. The addition 
of FYM or straw (FYM, NP+FYM and $\mathrm{NP}+\mathrm{S}$ ) treatments decreased soil bulk density significantly in comparison to that in control plots in all the layers. However, the decrease was more in upper soil layers (0-20 and 20$40 \mathrm{~cm})$ than in the lower layers (40-60, 60-80 and $80-100 \mathrm{~cm})$. Similar was the case with NP treatment, where BD was lower than that in CT treatment at 0-20 and 20-40 cm depths. There were no statistically significant differences in $\mathrm{BD}$ among treatments below 40 cm depth.

The distribution of SOC with depth was dependent on the use of various fertilizers [Fig. 14b]. The highest SOC concentration was obtained for $0-20 \mathrm{~cm}$ depth and decreased with depth for all treatments. The SOC concentration in 0-20, 20-40 and 40-60 $\mathrm{cm}$ depths increased significantly by farmyard manure or straw application. At the 0-20 and 20-40 cm soil depths, SOC was highest in $\mathrm{NP}+\mathrm{FKM}$ followed by $\mathrm{NP}+\mathrm{S}$ and $\mathrm{FYM}$ treatments and the least in $\mathrm{CK}$ treatment. However, the SOC concentration below 60 $\mathrm{cm}$ depth was statistically similar among different treatments. This finding indicated that long-term chemical NP fertilizer alone can increase soil $\mathrm{C}$ sequestration, which has been confirmed by other long-term fertilizer (Wu et al., 2005).

The effects of fertilization on SOC storage showed a similar trend to SOC concentration [Fig. 14b]. The topsoil $(0-20 \mathrm{~cm})$ had the maximum levels of cumulative SOC storage in the $1 \mathrm{~m}$ soil depth for the CK, N, NP, $\mathrm{FYM}, \mathrm{NP}+\mathrm{S}$ and $\mathrm{NP}+\mathrm{FYM}$ treatments, accounting for $24 \%, 23 \%, 27 \%, 30 \%, 31 \%$ and $31 \%$, respectively. At the $20-40 \mathrm{~cm}$ and 40-60 cm soil layers, the SOC stocks of the $\mathrm{NP}, \mathrm{FYM}, \mathrm{NP}+\mathrm{S}$ and $\mathrm{NP}+\mathrm{FYM}$ treatments were significantly higher by $17 \%, 21 \%, 25 \%$ and $37 \%$ and $5.3 \%, 8.1 \%, 7.3 \%$ and $11 \%$, respectively, than that of the CK. The differences of SOC storage between different treatments were not significant in the 60-80 $\mathrm{cm}$ and $80-100 \mathrm{~cm}$ soil layers. SOC storages were significantly different between fertilization treatments in the $0-100 \mathrm{~cm}$ profile. Compared with the $\mathrm{CK}$ treatment, SOC storages of the NP+FYM, NP+S, FYM and NP treatments within the $0-100 \mathrm{~cm}$ soil depth were increased by nearly 30, 24, 20 and $12 \%$, respectively. Kanchikerimath and Singh (2001) also found that inorganic fertilizers plus organic material increased the SOC content of the soil. The reasons for the higher SOC in manure soils at deeper depths include the following. First, the crop rooting depth between organic manure and inorganic fertilizer soils differ. The organic manure soils can be favourable for the growth of roots into deeper layers due to the relatively loose soil and high soil water content. Second, SOC in organic manure soils can also move to lower depths through earthworm burrows and leaching (Lorenz and Lal, 2005).

Liu et al., (2013) revealed that the particulate organic $\mathrm{C}$ was found stratified along the soil depth. A higher POC was found in surface soil decreasing with depth [Fig. 14c]. At the 0-20 cm, POC content under NP+FYM, $\mathrm{NP}+\mathrm{S}$ and FYM were 103, 89 and $90 \%$ greater than under $\mathrm{CK}$, respectively. In 20-40 $\mathrm{cm}$ and 40-60 $\mathrm{cm}$ soil layers, NP+FYM had maximum POC which was significantly higher than $\mathrm{NP}+\mathrm{S}$ and $\mathrm{FYM}$ treatments. Even though POC below $60 \mathrm{~cm}$ depth was statistically similar among fertilization treatments, the general trend was for increased POC with farmyard manure or straw application down to $100 \mathrm{~cm}$ soil depth. Irrespective of soil depths, NP+FYM invariably showed higher content of DOC over all other treatments. The $\mathrm{CK}$ and $\mathrm{N}$ treatments showed lower content of DOC. The DOC concentrations in $0-20 \mathrm{~cm}, 20-40$ $\mathrm{cm}$ and 40-60 $\mathrm{cm}$ depths were observed highest for NP+FYM followed by $\mathrm{NP}+\mathrm{S}$ and FYM, and both of them were significant 
higher than NP [Fig. 14c]. However, in the deeper layers $(60-80 \mathrm{~cm}$ and $80-100 \mathrm{~cm})$, the difference in DOC among the treatments was not significant. The MBC differences among treatments not only presented in the surface soil layers, but also presented at deeper depths in the profile. In our study, MBC showed a significant effect at different fertilizer treatments [Fig. 14c]. The SOC concentration in $0-80 \mathrm{~cm}$ depth increased significantly by farmyard manure or straw application. The mean $\mathrm{MBC}$ content in $0-80 \mathrm{~cm}$ profile was $82 \%$ higher in $\mathrm{NP}+\mathrm{FYM}$ treatment than in $\mathrm{CK}$ treatment. The reason for this is that the $\mathrm{N}$ treatment may stimulate soil microbial activity, therefore increasing the $\mathrm{C}$ output. The increase in $\mathrm{C}$ mineralization might offset the increase in $\mathrm{C}$ input (Halvorson et al., 2002).

Anyanzwa et al., (2010) observed that the crop residues had an additive effect on crop production, soil organic carbon and soil total nitrogen. Crop rotation gave higher yields hence an attractive option to farmers. Longterm studies are needed to show the effects of crop residue, cropping systems and nutrient input on sustainability of SOM and crop productivity [Fig. 15a]. Gu et al., (2016) reported that LOC showed significant seasonal changes, where the maximum value occurred during February to March, after which content declined and remained lower prior to October [Fig. 15b]. Lower accumulation of LOC during the period from April to September was possibly attributable to high decomposition of recent organic material inputs, and high loss with runoff at this rainy time (Chen et al., 2004). Mulching practices did not alter the seasonal dynamic changes of LOC, but could increase its content, e.g., in March, ST and GT increased LOC by $167 \%$ and $122 \%$ respectively [Fig. 15b]. The higher values of LOC in ST and GT can possibly be attributed to the inputs from organic materials and root residues, as well as decreased losses with surface runoff as a result of mulching (Gale et al., 2000). Vicente et al., (2017) concluded that the SOC concentration in PC was on average, $2.8(0-5$ $\mathrm{cm}$ soil) and $2.0(5-15 \mathrm{~cm})$ times higher than in bare soils of NPC, and the pool of protected SOC in the top $15 \mathrm{~cm}$ was 2.1 times higher in the PC $\left(17.9 \mathrm{mgCg}^{-1}\right)$ compared to NPC $\left(8.5 \mathrm{mgCg}^{-1}\right)$ [Fig. 15c].

Aggregation process in the soil is important, and it plays a considerable role in improving the soil health. Also, the aggregation process is important in improving the carbon sequestration in soil. This indicates that tillage affects soil fertility through changes in soil structure in this subtropical soil ecosystem. CT significantly reduces macro-aggregates to smaller ones, thus aggregate stability was reduced by $35 \%$ compared with RNT, further indicating that tillage practices led to soil structural damage. Long-term conservation tillage and residue retention significantly increased the organic $\mathrm{C}$ content in soil by increasing organic $\mathrm{C}$ in all aggregates, whereas the increase in organic $\mathrm{C}$ in inorganic fertilizer-added soils was mainly because of the enhancement in organic $\mathrm{C}$ content in macro-aggregates and the silt + clay fraction.

The labile organic $\mathrm{C}$ fractions and SOC were highly correlated with each other and MWD, GMD, and macro-aggregate C. Labile C fractions were sensitive to SOC changes, with sensitivity decreasing in the order: $\mathrm{POC}>$ DOC and MBC. C sequestration can be enhanced by increasing the proportion of $\mathrm{C}$ rich macro-aggregates in soils through the utilization of conservation tillage. Therefore, crop residue incorporation will enhance soil organic matter and will improve soil structure. Soil organic C is a key element in the valuation of natural resources and the evaluation of how management affects soil quality and ecosystem services derived from soil. A key to success will be to consider the 
agronomic, ecological and environmental constraints within a particular farm setting.

Conventional tillage (CT) significantly reduces macro-aggregates to smaller ones, thus aggregate stability was reduced by $35 \%$ compared with conservation system (CS), further indicating that tillage practices led to soil structural damage. The concentrations of SOC and other nutrients are also significantly higher under CS than $\mathrm{CT}$, implying that CS may be an ideal enhancer of soil productivity in this sub-tropical ecosystem through improving soil structure which leads to the protection of SOM and nutrients, and the maintenance of higher nutrient content. The average concentration of particulate organic carbon (POC), dissolved organic carbon (DOC) and microbial biomass carbon (MBC) in organic manure plus inorganic fertilizer treatments $(\mathrm{NP}+\mathrm{S}$ and $\mathrm{NP}+\mathrm{FYM})$ in $0-60 \mathrm{~cm}$ depth were increased by $64.9-91.9 \%, 42.5$ $56.9 \%$, and $74.7-99.4 \%$, respectively, over the CK treatment.

\section{References}

An, S.S., Mentler, A., Mayer, H., and Blum, W.E. 2010. Soil aggregation, aggregate stability, organic carbon and nitrogen in different soil aggregate fractions under forest and shrub vegetation on the Loess Plateau, China. Catena 81: 226-233.

Anyanzwa, H., Okalebo, J.R., Othieno, C.O., Bationo, A., Waswa, B.S., and Kihara, J. 2010. Effects of conservation tillage, crop residue and cropping systems on changes in soil organic matter and maize-legume production: a case study in Teso District. Nutr. Cycl. Agroecosyst. 88(1): 39-47.

Bhattacharyya, P., Roy, K.S., Neogi, S., Adhya, T.K., Rao, K.S., and Manna, M.C. 2012. Effects of rice straw and nitrogen fertilization on greenhouse gas emissions and carbon storage in tropical flooded soil planted with rice. Soil Tillage Res. 124: 119-130.

Brady, N.C. and Weil, R.R. 2002. The Nature and Properties of Soil. 13th Edition, Prentice Hall, Upper Saddle River, New Jersey.

Brevik, E., Fentton, T., and Moran, L. 2002. Effect of soil compaction on organic carbon amounts and distribution southcentral Iowa. Environ. Pollut. 116: 137141.

Chen, A.H., Houa, R., Gonga, Y., Li B.H., Fan, C.M. and Kuzyakov D.Y. 2009. Effects of 11 years of conservation tillage on soil organic matter fractions in wheat monoculture in Loess Plateau of China. Soil Til. Res. 106: 85-94.

Chen, G.S. Yang, Y.S., Xie, J.S., Li, L., and Gao, R. 2004. Soil biological changes for a natural forest and two plantations in subtropical China. Pedosphere, 14(3): 297-304.

Chen, X., Wang, X., Liebman, M., Cavigelli, M., and Wander, M. 2014. Influence of Residue and Nitrogen Fertilizer Additions on Carbon Mineralization in Soils with Different Texture and Cropping Histories. PLoS ONE 9(7): e103720.doi:10.1371/ journal. pone. 0103720

Conforti, M., Luca, F., Scarciglia, F., Matteucci, G., and Buttafuoco, G. 2016. Soil carbon stock in relation to soil properties and landscape position in a forest ecosystem of southern Italy (Calabria region). Catena 144: 23-33.

Cui, J., Li, Z., Liu, Z., Ge, B., Fang, C., Zhou, C., and Tang, B. 2014. Physical and chemical stabilization of soil organic carbon along a 500-year cultivates soil chronosequence originating from estuarine wetlands: Temporal patterns and land use effects. Agric Ecosyst Environ. 196: 10-20.

Denga, L., Wang, K., Tang, Z., and Shangguan, Z. 2016. Soil organic 
carbon dynamics following natural vegetation restoration: Evidence from stable carbon isotopes $\left(\alpha^{13} \mathrm{C}\right)$. Agric Ecosyst Environ. 221:235-244.

Dhaliwal J, Kukal SS, Sharma S. 2018. Soil organic carbon stock in relation to aggregate size and stability under treebased cropping systems in Typic Ustochrepts. Agroforestry Syst. 92(2):275-284.

Dutta, S., Singhal, P., Agrawal, P., Tomer, R., Kritee, K., Khurana, E. and Jayaram, B. 2006. A physicochemical model for analyzing DNA sequences. J Chem Inf Model 46(1):78-85.

Duval, M.E., Galantini, J.A., Capture, J.E., and Martinez, J.M. 2016. Winter cover crops in soybean monoculture: Effects on soil organic carbon and its fractions. Soil Tillage Res. 161: 95-105.

Franzluebbers, A.J. 2002. Soil organic matter stratification ratio as an indicator of soil quality. Soil Tillage Res. 66: 95-106.

Fu, X.L., Shao, M.A., Wei, X.R., and Robertm, H. 2010. Soil organic carbon and total nitrogen as affected by vegetation types in Northern Loess Plateau of China, Geoderma 155: 3135 .

Gale, W.J., Cambardella, C.A., and Bailey, T.B. 2000. Root-derived carbon and the formation and stabilization of aggregates. Soil Sci Soc Am J. 64: 20120

Gao, Z. X., Zhou, J. B., Wang, X., et al., 2010. Effects of different fertilizer treatments on content and characteristics of dissolved organic carbon in soil. Acta Pedologica Sinica, 47(1): 115-121

Ghosh, A., Bhattacharyyaa, R., Dwivedi, B.S., Meena, M.C., Agarwal, B.K., Mahapatra, P., Shahi, D.K., Salwani, R., and Agnihorti, R. 2016. Temperature sensitivity of soil organic carbon decomposition as affected by long-term fertilization under a soybean based cropping system in a sub-tropical Alfisol. Agric Ecosyst Environ. 233: 202-213.

Ghosh, B.N., Meena, V.S., Alam, N.M., Dogra, P., Bhattacharyya, R., Sharma, N.K., and Mishra, P.K. 2016. Impact of conservation practices on soil aggregation and the carbon management index after seven years of maize-wheat cropping system in the Indian Himalayas. Agric. Ecosyst. Environ. 216: 247-257.

Google Scholar

Groenendijk, F.M., Condron, L.M., and Rijkse, W.C. 2002. Effect of afforestation on organic carbon, nitrogen, and sulfur concentration in New Zealand hill country soils. Geoderma 108: 91-100.

Guckland, A., Jacob, M., Flessa, H., Thomas, F.M., and Leuschner, C. 2009. Acidity, nutrient stocks, and organic-matter content in soils of a temperate deciduous forest with different abundance of European beech (Fagus sylvatica L.). J. Plant Nutr. Soil Sci. 172:500-511.

Guo, L.J., Zhang, Z.S., Wang, D.D., Li, C.F., and Cao, C.G. 2012. Effects of shortterm conservation management practices on soil organic carbon fractions and microbial community composition under a rice-wheat rotation system. Biol. Fertil. Soils 5: 65-75.

Halvorson, A.D., Wienhold, B.J., and Black, A.L. 2002. Tillage, nitrogen, and cropping system effects on soil carbon sequestration. Soil Sci Soc Am J 66: 906-912

Haynes, R.J. 2005. Labile organic matter fractions as central components of the quality of agricultural soils: an overview. Adv.Agron. 85: 221-268

Hungria, M., Franchini, J.C., Brandão-Junior, O., Kaschuk, G., and Souza, R.A. 2009. 
Soil microbial activity and crop sustainability in a long-term experiment with three soil-tillage and two croprotation systems. Appl. Soil Ecol. 42: 288-296.

Juan, H.U., Jinggui, W.U., and Xiaojing, Q.U. 2018. Decomposition characteristics of organic materials and their effects on labile and recalcitrant organic carbon fractions in a semi-arid soil under plastic mulch and drip irrigation. $J$ Arid Land 10 (1): 115-128.

Kanchikerimath, M., and Singh, D. 2001. Soil organic matter and biological properties after 26 years of maize-wheat-cowpea cropping as affected by manure and fertilization in a Cambisol in semiarid region of India. Agric Ecosyst Environ 86: $155-162$

Katterera, T., Borjesson, G., and $\mathrm{H}$. Kirchmann, H. 2014. Changes in organic carbon in topsoil and subsoil and microbial community composition caused by repeated additions of organic amendments and $\mathrm{N}$ fertilisation in a long-term field experiment in Sweden. Agric Ecosyst Environ. 189: 110-118.

Kaur, T., Brar, B.S., Dhillon, N.S. 2008. Soil organic matter dynamics as affected by long-term use of organic and inorganic fertilizers under maize-wheat cropping system. Nutr. Cycl. Agroecosyst., 81: 59-69.

Krishna, C. A., Majumder, S.P., Padhan, D., Badole, S., Datta, A., Mandal, B., and Gade, K.R. 2018. Carbon dynamics, potential and cost of carbon sequestration in double rice cropping system in semi-arid southern India. $J$. Soil Sci Plant Nutri, 18 (2): 418-434

Kuhn, N.J., Hu, Y., Bloemertz, L., He, J., Li, H., and Greenwood, P. 2016. Conservation tillage and sustainable intensification of agriculture: regional vs. global benefit analysis. Agric Ecosyst Environ. 216: 155-165
Lal, R. 2004a. Soil carbon sequestration impacts on global climate change and food security. Science 304: 1623-1627.

Lazicki, P.A. 2011. Effect of rotation, organic inputs and tillage on crop performance and soil quality in conventional and low-input rotations in central Iowa. M.Sc. Thesis. University of Illinois, Champaign-Urban

Li, X.G., Zhang, P.L., Yin, P., Li, Y.K., Ma, Q.F., Long, R.J., and Li, F.M. 2009. Soil organic carbon and nitrogen fractions and water-stable aggregation as affected by cropping and grassland reclamation in an arid sub-alpine soil. Land. Degrad. Dev. 20: 176-186.

Liang, Y., Han, X. Z., Song, C., et al., 2011. Impacts of returning organic materials on soil labile organic carbon fractions redistribution of mollisol in northeast China. Scientia Agricultura Sinica, 44(17): 3565-3574.

Lihua, Zhang, Ruifeng Zhao, and Zhongkui Xie. 2014. Response of soil properties and $\mathrm{C}$ dynamics to land-use change in the west of Loess Plateau, Soil Science and Plant Nutrition, 60:4, 586-597, DOI: $10.1080 / 00380768.2014 .922407$

Liu, E., Teclemariam, S.G., Yan, C., Yu, J., Gu, R., Liu, S., He, W., and Liu, Q. 2014. Long-term effects of no-tillage management practice on soil organic carbon and its fractions in the northern China. Geoderma 213: 379-384

Liu, E., Yan, C., Mei, X., Zhang, Y., and Fan, T. 2013. Long-Term Effect of Manure and Fertilizer on Soil Organic Carbon Pools in Dryland Farming in Northwest China. PLoS ONE 8 (2): e56536. https://doi.org/10.1371/journal.pone.005 6536

Lorenz, K., and Lal, R. 2005. The depth distribution of soil organic carbon in relation to land use and management and the potential of carbon 
sequestration in subsoil horizons. $A d v$ Agron 88: 35-66

Ma, Z., Chen, J., Lyu, X., Liu, Li-li., and Siddique, K.H.M. 2016. Distribution of soil carbon and grain yield of spring wheat under a permanent raised bed planting system in an arid area of northwest China. Soil Tillage Res. 163: 274-281.

Meena, V.S., Mondal, T., Pandey, B.M., Mukherjee, A., Yadav, R.P., Choudhary, M., Singh, S., Bisht, J.K., and Pattanayak, A. 2018. Land use changes: Strategies to improve soil carbon and nitrogen storage pattern in the mid-Himalaya ecosystem, India. Geoderma 321: 69-78.

Mobley, M.L., Lajtha, K., Kramer, M.G., Bacon, A.R., Heine, P.R., and Richter, D.D. 2015. Surficial gains and subsoil losses of soil carbon and nitrogen during secondary forest development. Glob Change Biol. 21: 986-996.

Naresh, R.K., Gupta, R.K. and Panwar, A.S. 2018. Spatial and temporal variations of soil organic carbon fractions and soil carbon storage in ricewheat cropping system under varying tillage, straw and fertilizer management. Journal of Pharmacognosy and Phytochemistry 7(3): 1667-1690.

Naresh, R.K., Gupta, R.K., Dhaliwal, S.S. and Vivek 2018. Soil organic carbon stabilization for different land uses and soil management practices in a ricewheat system of the North West indoGangetic plains. Journal of Pharmacognosy and Phytochemistry 7(3): 1716-1735.

Naresh, R.K., Gupta, R.K., Minhas, P.S., Rathore, R.S., Dwivedi, A, Kumar, M., Tyagi, S., Kumar, V., Kumar, P., Purushottam, Kumar, Y., Mahajan, N.C., Kumar, A., Pratap, B. and Singh, O. 2017.Toward optimal soil organic carbon sequestration with effects of agricultural management practices and climate change in upland soils of subtropical India. International Journal of Chemical Studies 5(2): 433-442.

Nath, A.J., Bhattacharyya, T., Deka, J., Das, A.K., and Ray, S.K. 2015. Management effect on soil organic carbon pools in lowland rain-fed paddy growing soil. $J$. Tropical Agri. 53 (2): 131-138.

Poeplau, C., and Don, A. 2013. Sensitivity of soil organic carbon stocks and fractions to different land-use changes across Europe. Geoderma 192: 189-201.

Poeplau, C., Lisa Reiter, L., Berti, A., and Kätterer, T.2017.Qualitative and quantitative response of soil organic carbon to 40 years of crop residue incorporation under contrasting nitrogen fertilisation regimes. Soil Res. 55: 1-9

Saha, Debasish, Kukal, S.S., and Bawa, S.S. 2014. Soil organic carbon stock and fractions in relation to land use and soil depth in the degraded shiwaliks hills of lower Himalayas. Land Degrad. Dev. 25: 407-416.

Sainju, U.M., Lenssen, A.W., CaesarTonThat, T., Jabro, J.D., Lartey, R.T., Evans, R.G., and Allen, B.L. 2012. Dryland soil nitrogen cycling influenced by tillage, crop rotation, and cultural practice. Nutr. Cycl. Agroecost. 93: 309-322.

Scherer-Lorenzen, M. 2008. Functional diversity affects decomposition processes in experimental grasslands. Funct. Ecol. 22(3): 547-555.

Sheng, H., Zhou, P., Zhang, Y.Z., Kuzyakov, Y., Zhou, Q., Ge, T., Wang, C. 2015. Loss of labile organic carbon from subsoil due to land-use changes in subtropical China. Soil Biol Biochem. 88:148-157

Singh, K. P., Ghoshal, N., and Singh, S. 2009. Soil carbon dioxide flux, carbon sequestration and crop productivity in a tropical dryland agroecosystem: 
influence of organic inputs of varying resource quality. Applied Soil Ecology, 42(3): 243-253.

Singh, P., Heikkinen, J., Ketoja, E., Nuutinen, V.,Palojärvi, A., Sheehy, J., Esala, M., Mitra, S., Alakukku, L., and Regina, K. 2015. Tillage and crop residue management methods had minor effects on the stock and stabilization of topsoil carbon in a 30-year field experiment. Sci Total Environ, 518-519: 337-344.

Soto-Pinto, L., Anzueto, M., Mendoza, J., Ferrer, G., and de Jong, B. 2010. Carbon sequestration through agroforestry in indigenous communities of Chiapas, Mexico. Agrofor. Syst. 78: 39-51.

Stockmann, U., Adams, M.A., Crawford, J.W., Field, D.J., Henakaarchchi, N. n Jenkins, M. et al., 2013. The knowns, known unknowns and unknowns of sequestration of soil organic carbon. Agric. Ecosyst. Environ. 164:80-99.

Su, Y.Z., Liu, W.J., Yang, R., and Chang, X.X. 2009: Changes in soil aggregate, carbon, and nitrogen storages following the conversion of cropland to alfalfa forage land in the marginal oasis of northwest China. Environ. Manag. 43:1061-1070.

Tang, X.Y., Liu, S.G., Liu, J.X., and Zhou, G.Y. 2010. Effects of vegetation restoration and slope positions on soil aggregation and soil carbon accumulation on heavily eroded tropical land of Southern China. J. Soils Sedim. 10: 505-513.

Tang, Z., and Nan, Z. 2012. The potential of cropland soil carbon sequestration in the Loess Plateau, China. Mitig. Adapt. Strateg. Glob. Change doi:http://dx.doi.org/10.1007/s11027012-9397-z.

Tarnocai, C., Canadell, J. G., Schuur, E. A. G. Kuhry, P. Mazhitova, G. and Zimov, S.2009.Soil organic carbon pools in the northern circumpolar permafrost region. GLOBAL BIOGEOCHEMICAL CYCLES, VOL. 23, GB2023, doi:10.1029/2008GB003327.

Thomazini, A., Mendonça, E.S., ICardoso, I.M., and Garbin, M.L. 2015. SOC dynamics and soil quality index of agroforestry systems in the Atlantic rainforest of Brazil. Geoderma Regional 5:15-24.

Vicente-Vicente, J.L., Muñoz, G., HinojosaCentenod. M.B., Smith, P., and GarciaRuiz, R. 2017. Carbon saturation and assessment of soil organic carbon fractions in Mediterranean rainfed olive orchards under plant cover management. Agric Ecosys Environ. 245: 135-146.

Wang, X., Yang, H., Liu, J., Wu, J., Chen, W., Wu, Jie. Zhu, L., and Bian, X. 2015. Effects of ditch-buried straw return on soil organic carbon and rice yields in a rice-wheat rotation system. Catena 127: 56-63.

Wu, J.M., Peng, H., Ji, X.H., Shi, L.H., Tian, F.X., and Liu, Z.B. 2010. Effect of patterns of straw returning to soil on the cultivated soil organic carbon accumulation in double-crop rice system. Ecol. Environ. Sci. 19: 23602365

Wu, T., Schoenau, J.J., Li, F., Qian, P., Malhi, S.S., Shi, Y. 2005. Influence of fertilization and organic amendments on organic- carbon fractions in Heilu soil on the loess plateau of China. J Plant Nutr Soil Sci 168: 100-107.

Yu, Y., Huang, Y., and Zhang, W. 2013. Projected changes in soil organic carbon stocks of China's croplands under different agricultural managements, 2011-2050. Agric Ecosys Environ. 178: $109-120$

Zhang, H., Zhang, Y., Yan, C., Liu, E., and Chen, B. 2016. Soil nitrogen and its 
fractions between long-term conventional and no-tillage systems with straw retention in dry-land farming in northern China. Geoderma 269:138144.

Zhang, J., Wang, X., Wang, J., and Meng, Q. 2018. Characteristics of Soil Organic Matter and Carbon and Nitrogen Contents in Crops/Plants: Land Use Impacts. Carbon Cycle in the Changing Arid Land of China pp 41-53.

Zhao, F., Yang, G., Han, X., Feng, Y., and Ren, G. 2014. Stratification of Carbon Fractions and Carbon Management Index in Deep Soil Affected by the Grain-to- Green Program in China. PLoS ONE 9(6): e99657. doi:10.1371/journal.pone.0099657
Zhao, Y.G., Liu, X.F., Wang, Z.L., and Zhao, S.W. 2015. Soil organic carbon fractions and sequestration across a 150 -yr secondary forest chronosequence on the Loess Plateau, China. Catena 133: 303-308.

Zhu H, Wu J, Guo S, Huang D, Zhu Q, Ge T et al., 2014. Land use and topographic position control soil organic $\mathrm{C}$ and $\mathrm{N}$ accumulation in eroded hilly watershed of the Loess Plateau. Catena.120:64-72.

Zimov, S. A., Davydov, S. P., Zimova, G. M., Davydova, A. I., Schuur, E. A. G., Dutta, K. and Chapin, F. S. 2006. Permafrost carbon: Stock and decomposability of a globally significant carbon pool. Geophysical Research Letters 33, L20502, doi:10.1029/2006GL027484.

\section{How to cite this article:}

Rajendra Kumar, R.K. Naresh, Mohan Lal, D.K. Sachan, N.C. Mahajan, Sanjeev Singh, Omkar Singh, Rahul Kumar and Vishal Chaudhary. 2018. Can Conservation Tillage and Residue Management Effects on Sensitivity of Labile Soil Organic Carbon Fractions and Soil Organic Carbon Stocks in Sub-Tropical Ecosystems: A Review. Int.J.Curr.Microbiol.App.Sci. 7(11): 2063-2089. doi: https://doi.org/10.20546/ijcmas.2018.711.234 